\title{
Reviews and syntheses: Ironing out wrinkles in the soil phosphorus cycling paradigm
}

\author{
Curt A. McConnell ${ }^{1}$, Jason P. Kaye ${ }^{2}$, and Armen R. Kemanian ${ }^{1}$ \\ ${ }^{1}$ Department of Plant Science, Pennsylvania State University, University Park, PA, 16802, USA \\ ${ }^{2}$ Department of Ecosystem Science and Management, Pennsylvania State University, University Park, PA, 16802, USA \\ Correspondence: Curt A. McConnell (czm66@psu.edu) and Armen R. Kemanian (kxa15@psu.edu)
}

Received: 11 April 2020 - Discussion started: 5 May 2020

Revised: 10 August 2020 - Accepted: 18 September 2020 - Published: 6 November 2020

\begin{abstract}
Soil phosphorus (P) management remains a critical challenge for agriculture worldwide, and yet we are still unable to predict soil $\mathrm{P}$ dynamics as confidently as that of carbon $(\mathrm{C})$ or nitrogen $(\mathrm{N})$. This is due to both the complexity of inorganic $\mathrm{P}\left(\mathrm{P}_{\mathrm{i}}\right)$ and organic $\mathrm{P}\left(\mathrm{P}_{\mathrm{O}}\right)$ cycling and the methodological constraints that have limited our ability to trace $\mathrm{P}$ dynamics in the soil-plant system. In this review, we describe the challenges for building parsimonious, accurate, and useful biogeochemical models that represent $\mathrm{P}$ dynamics and explore the potential of new techniques to usher $\mathrm{P}$ biogeochemistry research and modeling forward. We conclude that research efforts should focus on the following: (1) updating the McGill and Cole (1981) model of $\mathrm{P}_{\mathrm{o}}$ mineralization by clarifying the role and prevalence of biochemical and biological $\mathrm{P}_{\mathrm{o}}$ mineralization, which we suggest are not mutually exclusive and may co-occur along a continuum of $\mathrm{P}_{\mathrm{O}}$ substrate stoichiometry; (2) further understanding the dynamics of phytate, a six $\mathrm{C}$ compound that can regulate the poorly understood stoichiometry of soil $\mathrm{P}$; (3) exploring the effects of $\mathrm{C}$ and $\mathrm{P}_{\mathrm{o}}$ saturation on $\mathrm{P}$ sorption and $\mathrm{P}_{\mathrm{o}}$ mineralization; and (4) resolving discrepancies between hypotheses about $\mathrm{P}$ cycling and the methods used to test these hypotheses.
\end{abstract}

\section{Introduction}

Managing agricultural soil phosphorus (P) to maximize crop productivity and minimize $\mathrm{P}$ pollution is one of the critical challenges of contemporary agriculture. Our current understanding of soil $\mathrm{P}$ cycling lags that of carbon (C) and nitrogen (N; Reed et al., 2015), and that lag is pronounced in simulation models (e.g., Vadas et al., 2006). Most P cycling compo- nents of biogeochemical models are structured after $\mathrm{C}$ and $\mathrm{N}$, despite key differences between the biogeochemical cycling of the three elements. Soil $\mathrm{P}$ has a significant inorganic component in addition to an organic one, both of which can cycle independently of C and N (McGill and Cole, 1981; Condron et al., 2005). Unlike $C$ and $N$, investigating $P$ cycling is limited by the existence of one $\mathrm{P}$ stable isotope ( $\mathrm{C}$ and $\mathrm{N}$ have two each), making tracing studies dependent on $\mathrm{P}$ radioisotopes that are short-lived and hazardous. Phosphate-bound stable oxygen isotopes can also be used to trace $\mathrm{P}$ but are subject to biotically mediated fractionation that complicate the interpretation of abiotic P transformations (Blake et al., 2005; Angert et al., 2011).

Gaps in our understanding of the $\mathrm{P}$ cycle are reflected in model conceptualizations and in model results that are rather uncertain regarding $\mathrm{P}$ cycling (Radcliffe et al., 2009). The mismatch or poor correlation between analytical chemical $\mathrm{P}$ pools and conceptual P pools (Gijsman et al., 1996) only compounds this uncertainty. A manifestation of these limitations in model prediction was the failure to predict increased soluble $\mathrm{P}$ losses as agricultural management shifts from till to no-till systems (Duncan et al., 2019), even though it was long known that while no-till reduces erosion it stratifies immobile nutrients. Vertical stratification of P coupled with hydrological connectivity between fields and waterways via runoff or tile drains led to enhanced transport of soluble $\mathrm{P}$ from fields to water (Radcliffe et al., 2015; Dodd and Sharpley, 2016). The collective inability to predict the behavior of $\mathrm{P}$ with the current nutrient models (Radcliffe et al., 2015; García et al., 2016) highlights the limited holistic understanding of P cycling. 


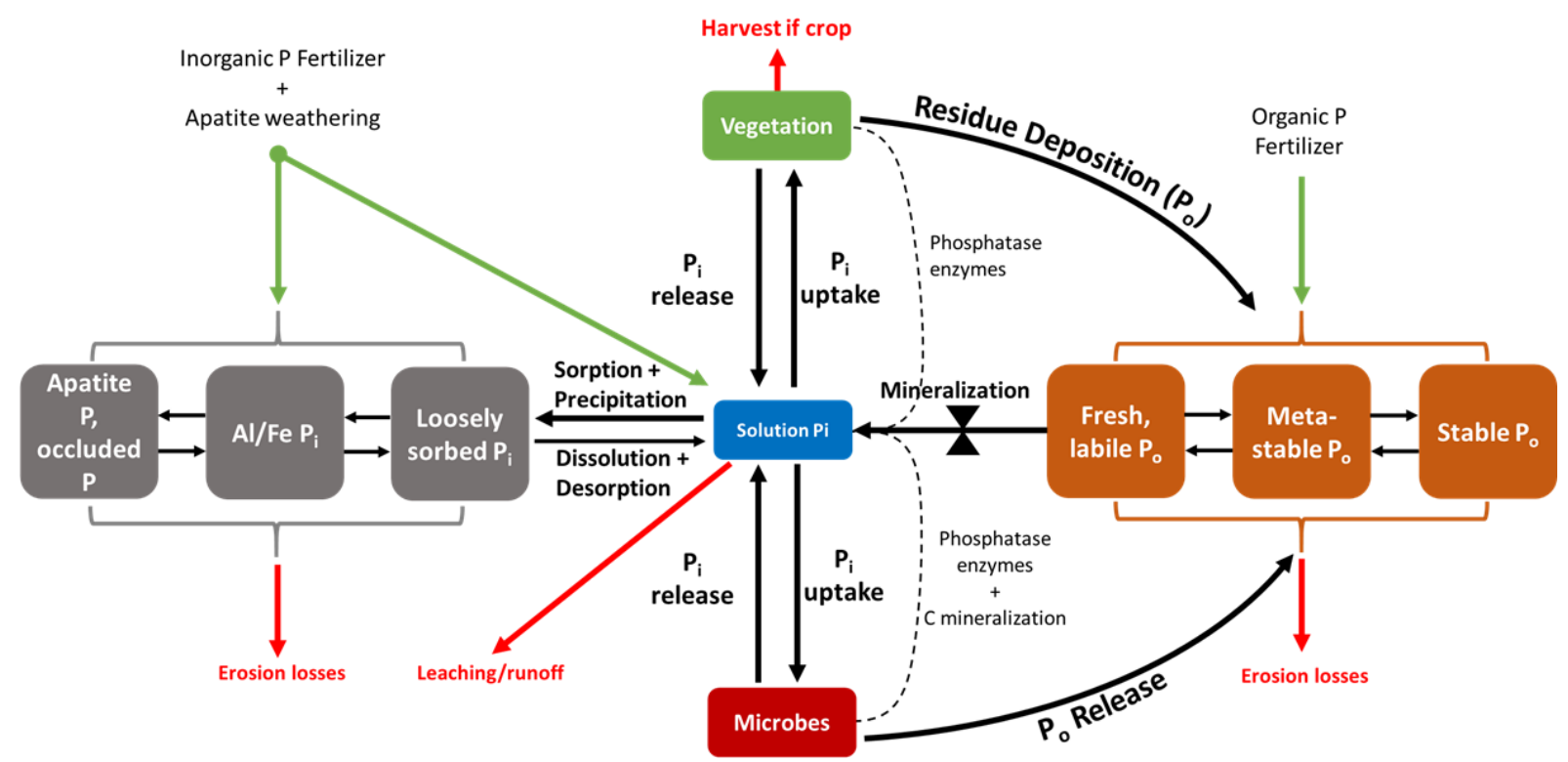

Figure 1. Conceptual diagram of the soil $\mathrm{P}$ cycle. $\mathrm{P}_{\mathrm{i}}$ and $\mathrm{P}_{\mathrm{o}}$ represent inorganic (gray) and organic (orange) phosphates, respectively. The $\mathrm{P}_{\mathrm{i}}$ and $\mathrm{P}_{\mathrm{O}}$ pools that are situated farthest from the depicted solution pool in this diagram are considered more stable. There are small amounts of organic $\mathrm{P}$ in the solution that are not explicitly depicted here. The bow tie represents the control that mineralization exerts on the transformation of $\mathrm{P}$ from $\mathrm{P}_{\mathrm{O}}$ pools to the solution pool. The dotted lines represent enzymes in the mineralization of $\mathrm{P}_{\mathrm{O}}$. There are other abiotic controls of mineralization excluded from this diagram.

The goal of this review is to identify gaps in soil P cycling research that contribute to the observation-model disconnect and to clarify the path forward for a more seamless integration of experimental and theoretical progress. The objectives are to review the (1) discrepancies in $\mathrm{P}_{\mathrm{O}}$ mineralization paradigms, (2) difficulties in incorporating phytate and $\mathrm{C}: \mathrm{P}$ stoichiometry into these paradigms, (3) dynamics of $\mathrm{C}$ and $\mathrm{P}_{\mathrm{O}}$ saturation, and (4) methodological challenges in measuring $\mathrm{P}$ content, distribution, and sorption. These specific subjects were selected based on the extent of diverging evidence and the degree of importance to the conceptualization, or reconceptualization, of soil $\mathrm{P}$ cycling.

\section{Overview of $P$ cycle}

In the soil-plant system, $\mathrm{P}$ exists in both inorganic $\left(\mathrm{P}_{\mathrm{i}}\right)$ and organic $\left(\mathrm{P}_{\mathrm{o}}\right)$ forms, whose relative abundance depends on edaphic, management, and climate conditions. Generally, $\mathrm{P}_{\mathrm{o}}$ makes up $35 \%-65 \%$, and sometimes up to $90 \%$, of total $\mathrm{P}$ in soil (Williams and Steinbergs, 1958; Harrison, 1987). Of the total P in most plant-soil systems, less than $10 \%$ is in living organisms (Ozanne, 1980; Arai and Sparks, 2007). Usually, less than $1 \%$ is in solution as either a dissolved organic species or as a free inorganic phosphate $\left(\mathrm{PO}_{4}\right)$ ion immediately useable by plants and microorganisms (Pierzynski, 1991; Frossard et al., 2000). For $\mathrm{PO}_{4}$ to become available in the soil solution for organism uptake, soil $\mathrm{P}_{\mathrm{i}}$ and soil $\mathrm{P}_{\mathrm{O}}$ must undergo abiotic and biotic transformations (Fig. 1).
Soil $\mathrm{P}_{\mathrm{i}}$ is either in a primary mineral form, precipitated as various inorganic phosphates (mainly as $\mathrm{AlPO}_{4}, \mathrm{FePO}_{4}$, and $\mathrm{CaPO}_{4}$ ), occluded by precipitates and other minerals, sorbed to mineral surfaces, or dissolved in the soil solution. In inorganic physiochemical pathways, $\mathrm{PO}_{4}$ is released into the solution by the dissolution of minerals, precipitates, and sorbed $\mathrm{P}_{\mathrm{i}}$ (Hedley et al., 1982; Cross and Schlesinger, 1995; Arai and Sparks, 2007). However, $\mathrm{PO}_{4}$ equilibrium favors sorption to the solid phase rather than desorption (Okajima et al., 1983; Menezes-Blackburn et al., 2016). $\mathrm{PO}_{4}$ undergoes sorption to mineral and colloid surfaces by electrostatic interaction or fast chemisorption (ligand exchange on external mineral sites).

Once $\mathrm{PO}_{4}$ is sorbed, it is either desorbed back to the soil solution or stabilized through further ligand exchange and slow incorporation into aggregates or clays (Holtan et al., 1988; Arai and Sparks, 2007). The methods of Hedley et al. (1982), later refined by Tiessen and Moir (1993), attempted to quantify $\mathrm{P}$ into pools along this continuum of $\mathrm{P}$ stabilization using sequential chemical extraction methods. The so-called Hedley fractionation is the most widely used method to quantify both $P_{i}$ and $P_{o}$ in fractions of varying lability and, indirectly, plant availability (Guppy et al., 2000).

The dissolution of solid phase $\mathrm{P}_{\mathrm{i}}$, and thus plant availability, depends on the ecosystem type (Cleveland et al., 2013; Bünemann, 2015), degree of soil development (Smeck, 1985), parent material (Bünemann et al., 2016), $P_{i}$ lability relative to $\mathrm{P}_{\mathrm{o}}$ (Pistocchi et al., 2018), and human inputs (Oehl et al., 2004). Soils in the early stages of development have 
low soil $\mathrm{P}_{\mathrm{o}}$ levels, so plant $\mathrm{P}$ acquisition relies on physiochemical processes for $\mathrm{P}_{\mathrm{i}}$ dissolution. These physiochemical processes also tend to control $\mathrm{P}$ availability for plants in agroecosystems supplied with $\mathrm{P}_{\mathrm{i}}$-rich fertilizers (Guo et al., 2000; Oehl et al., 2004; Bünemann, 2015). While $\mathrm{P}_{\mathrm{o}}$ can play a less significant role in agricultural systems (Bünemann, 2015), it can be an important $P$ source via mineralization in forested or highly weathered soils (Yang and Post, 2011; Cleveland et al., 2013; Bünemann, 2015), particularly when labile $\mathrm{P}_{\mathrm{i}}$ availability is low (Pistocchi et al., 2018).

The most common soil $\mathrm{P}_{\mathrm{o}}$ forms are orthophosphate monoesters, orthophosphate diesters, organic polyphosphates, and phosphonates (Turner et al., 2007). The orthophosphate monoester inositol phosphate comprises a significant fraction of total $P_{o}$ in most measured soils, principally due to its recalcitrance to mineralization (Turner et al., 2002). Sugar phosphate monoesters and phosphate diesters like DNA and RNA are more labile sources of mineralizable $\mathrm{P}_{\mathrm{o}}$ (Condron et al., 2005; Turner, 2008).

The agents responsible for $\mathrm{P}_{\mathrm{o}}$ mineralization are plant and microbial phosphatases that are periplasmic, membrane bound, or exuded into the soil solution. One function of extracellular enzymes is to depolymerize $\mathrm{P}_{\mathrm{o}}$ compounds, thus increasing their solubility and accessibility by microbes and plants (Quiquampoix and Mousain, 2005). After depolymerization, $\mathrm{P}_{\mathrm{o}}$ monomers may be assimilated by a microorganism, depending on compound-specific membrane transport proteins and other organismal and environmental controls such as the concentration of $\mathrm{P}_{\mathrm{i}}$ or the $\mathrm{P}_{\mathrm{o}}$ compound (Wanner, 1996; Heath, 2005; Quiquampoix and Mousain, 2005). However, only a few $\mathrm{P}_{\mathrm{o}}$ compounds are known to have direct transmembrane mobility, (Wanner, 1996) and to our knowledge, studies of direct $\mathrm{P}_{\mathrm{o}}$ uptake were not conducted in soils. The indirect uptake of $\mathrm{PO}_{4}$ from nontransportable $\mathrm{P}_{\mathrm{O}}$ compounds is regulated by phosphatase enzymes.

The mechanisms by which nontransportable $\mathrm{P}_{\mathrm{o}}$ is mineralized by microbes and plants are not clearly described in the literature; there is no unifying principle of $\mathrm{P}_{\mathrm{o}}$ mineralization considering recent advances in $\mathrm{P}$ biogeochemistry research. Initially, microbial $P_{0}$ mineralization was described similarly to $\mathrm{N}$ mineralization, whereby $\mathrm{P}_{\mathrm{O}}$ is mineralized in conjunction with $\mathrm{C}$ for energy and, thus, coupled to $\mathrm{C}$ dynamics (Thompson et al., 1954; Dalal, 1979). This biological $\mathrm{P}_{\mathrm{o}}$ mineralization model was challenged by McGill and Cole (1981), who posited a biochemical mineralization pathway. Under their definition, $\mathrm{P}_{\mathrm{o}}$ mineralization is driven by $\mathrm{P}$ demand met by phosphatase enzymes for the acquisition of $\mathrm{P}$ independent of $\mathrm{C}$. This model demonstrates a decoupling of $\mathrm{P}$ from $\mathrm{C}$ dynamics. Although this conceptualization has been generally accepted to occur under low labile $\mathrm{P}_{\mathrm{i}}$ conditions and has provided a potential explanation for the observed variability in soil and microbial nutrient stoichiometry, it is not complete (see Sect. 2).

The biological and biochemical pathways were regarded as mutually exclusive in the McGill and Cole model and, in some cases, continue to be (McGill and Cole, 1981; Heuck et al., 2015); however, it is simpler to assume that they coexist as, for example, in Goll et al. (2012) and Thum et al. (2019). $P_{o}$ mineralization can result in the acquisition of $P$, $\mathrm{C}$, or both, depending on the relative demand for either element or the relative lability of the $\mathrm{P}_{\mathrm{o}}$ substrate. The biological and biochemical terms are misleading as $\mathrm{P}_{\mathrm{o}}$ mineralization is always biochemical, i.e., phosphatase enzymes are used regardless of whether mineralization is driven by $\mathrm{C}$ or $\mathrm{P}$ demand. We propose to substitute $\mathrm{C}$-driven $\mathrm{P}_{\mathrm{o}}$ mineralization for biological and $\mathrm{P}$-driven $\mathrm{P}_{\mathrm{o}}$ mineralization for biochemical to distinguish the drivers leading to $\mathrm{P}_{\mathrm{o}}$ mineralization but without confounding the paths. We understand that $\mathrm{C}$-driven $\mathrm{P}_{\mathrm{o}}$ mineralization as a concept might be narrow in scope, as organic matter can be decomposed to mine organic $\mathrm{N}$ or sulfur as well, but the proposed language is unequivocal with respect to $\mathrm{P}$.

\section{Deconstructing $P_{0}$ mineralization and updating the McGill and Cole conceptual model}

McGill and Cole (1981) proposed that $\mathrm{P}_{\mathrm{o}}$ mineralization is independent of $\mathrm{C}$ and $\mathrm{N}$ mineralization (Smeck, 1985). However, this model is not uniformly true as elucidated by Condron et al. (2005) and further evidenced by recent research. Phosphatase enzymes play a key role in $\mathrm{P}_{\mathrm{o}}$ mineralization, yet phosphatase-mediated dephosphorylation may also be a requisite step in the acquisition of $\mathrm{C}$ (Spohn et al., 2015; Wang et al., 2016) as the polar $\mathrm{PO}_{4}$ groups may hinder direct $\mathrm{P}_{\mathrm{o}}$ uptake (Steenbergh et al., 2011). The extent to which and conditions under which either $\mathrm{C}$-driven or $\mathrm{P}$ driven $\mathrm{P}_{\mathrm{O}}$ mineralization occur are debated and require clarification (Smeck, 1985; Gressel et al., 1996; Oehl et al., 2004; Guppy and McLaughlin, 2009; Spohn and Kuzyakov, 2013; Heuck and Spohn, 2016). We will therefore highlight the evidence supporting both $\mathrm{P}_{\mathrm{o}}$ mineralization pathways and describe methodological limitations for measuring enzyme activity and $\mathrm{P}_{\mathrm{o}}$ mineralization.

\subsection{Evidence supporting P-driven $P_{0}$ mineralization}

Phosphatase enzymes can mineralize $\mathrm{P}_{\mathrm{O}}$ independent of the $\mathrm{C}$ moiety. There is substantial evidence relating $\mathrm{P}_{\mathrm{o}}$ depletion to increased phosphatase activity (Tarafdar and Jungk, 1987; Häussling and Marschner, 1989; Rojo et al., 1990; Speir and Cowling, 1991; Asmar et al., 1995; Chen et al., 2002), suggesting a mineralization pathway driven by $\mathrm{P}$ demand and decoupled from $\mathrm{C}$ dynamics. Increased phosphatase activity is also observed when decomposition is limited by $\mathrm{P}$ availability (Sinsabaugh et al., 1993), the soil has a high organic carbon $\left(\mathrm{C}_{\mathrm{o}}\right)$ content (Halstead, 1964), or organic material is added to a soil ( $\mathrm{Li}$ et al., 2015). Furthermore, there is a general negative relationship between available $\mathrm{P}_{i}$ and phosphatase activity, suggesting that $\mathrm{P}$-driven mineralization is 
suppressed when labile $\mathrm{P}_{\mathrm{i}}$ is no longer limiting (Juma and Tabatabai, 1977, 1978; Nannipieri et al., 1978; Spiers and McGill, 1979; Dick et al., 1988; Clarholm, 1993; Colvan et al., 2001; Moscatelli et al., 2005; Marklein and Houlton, 2012; Turner and Joseph Wright, 2014).

A tighter coupling of $\mathrm{C}$ mineralization with soil organic matter (SOM) $\mathrm{C}: \mathrm{N}$ ratios, rather than $\mathrm{C}: \mathrm{P}$ ratios (Heuck and Spohn, 2016), and a relatively poor correlation of $\mathrm{P}_{\mathrm{O}}$ with C or N (Yang and Post, 2011) indicates a greater independence of $\mathrm{P}$ mineralization from $\mathrm{C}$ than $\mathrm{N}$, a relationship captured by some simulation models (Yu et al., 2020). Furthermore, phosphatase activity responds faster to changes in mineral $\mathrm{P}$ availability than analogous $\mathrm{N}$ enzymes to $\mathrm{N}$ availability (Marklein et al., 2016) indicating the reliance on phosphatase enzymes for $\mathrm{P}$ acquisition under P-limited scenarios.

\subsection{Conflicting evidence in discerning P-driven and C-driven mineralization}

The relative contribution of plants and microbes in exuding phosphatase enzymes is unknown (Richardson et al., 2009 b). Because plants acquire $\mathrm{C}$ through photosynthesis, P-driven $\mathrm{P}_{\mathrm{O}}$ mineralization seems uncontroversial for autotrophic plants. In contrast, heterotrophic microbes may mineralize $\mathrm{P}_{\mathrm{O}}$ compounds for $\mathrm{C}$ or $\mathrm{P}$ rather than solely $\mathrm{P}$. Discriminating microbial and plant phosphatase activity in the rhizosphere and linking $\mathrm{C}$ - or $\mathrm{P}$-driven $\mathrm{P}_{\mathrm{o}}$ mineralization pathways to either organism is challenging.

Phosphatase activity is higher in the rhizosphere than in the bulk soil (Nannipieri et al., 1978; Häussling and Marschner, 1989), likely due to the greater abundance of $\mathrm{P}_{\mathrm{o}}$ substrates from decomposing root and microbial matter and combined plant and microbial activity in the rhizosphere (Jones et al., 2009; Spohn et al., 2015). The rhizosphere also tends to exhibit lower phosphatase activity with higher $\mathrm{P}_{\mathrm{i}}$ availability compared to the bulk soil (Hedley et al., 1983). This response cannot be conclusively linked to plants or microbes (Richardson et al., 2009b) because, with a few exceptions, plant and microbial phosphatases are indistinguishable (Nannipieri et al., 2011). Among the exceptions are the microbe-specific alkaline phosphatases, which, in some studies, have exhibited a negative response to $P_{i}$ fertilization when measured in the rhizosphere (Spohn et al., 2015), indicating an active microbe-mediated $\mathrm{P}$-driven $\mathrm{P}_{\mathrm{o}}$ mineralization. It must be noted, however, that alkaline phosphatases are only a subset of the microbially produced phosphatase enzymes and are produced in neutral to basic conditions (Juma and Tabatabai, 1978), which cautions against broad generalizations.

Outside of the rhizosphere in the bulk soil, it has been shown that the alkaline phosphatase activity response to $\mathrm{P}_{\mathrm{i}}$ availability is subdued (Spohn et al., 2015) or even positive (Colvan et al., 2001). This pattern is consistent with C-driven $\mathrm{P}_{\mathrm{O}}$ mineralization by nonrhizosphere microbes, stripping the $\mathrm{P}$ group as a prerequisite for further $\mathrm{C}$ processing (Spohn and Kuzyakov, 2013; Spohn et al., 2015). Supporting this interpretation, bulk or incubated soil isolated from the roots (with phosphatases more likely of microbial origin) have not shown a decline in either acid or alkaline phosphatase activity when $\mathrm{P}_{\mathrm{i}}$ availability increased (Adams and Pate, 1992; Lima et al., 1996).

Additionally, some studies have either found no relationship between $\mathrm{P}_{\mathrm{o}}$ mineralization and phosphatase activity (Dissing Nielsen and Eiland, 1980; Trasar-Cepeda et al., 1991; Chen et al., 2000; Allison and Vitousek, 2005) or did not observe a negative relationship of phosphatase activity with $\mathrm{P}_{\mathrm{i}}$ availability or $\mathrm{P}_{\mathrm{i}}$ fertilization (Halstead, 1964; Harrison, 1983; Li et al., 2015). The lack of an immediate negative response to $P_{i}$ availability may be caused by recalcitrant phosphatase enzymes stabilized by soil minerals and colloids that remain active in the soil (Clarholm, 1993; Turner and Joseph Wright, 2014). Turner and Wright (2014) proposed that longer term studies must be conducted to ensure that a change in overall phosphatase production can be observed. But an equally plausible explanation for the lack of a phosphatase response to $P_{i}$ availability may be that microbes are releasing phosphatase as a means of $\mathrm{C}$ acquisition (Spohn and Kuzyakov, 2013; Heuck et al., 2015), so phosphatase production can be, on occasion, unrelated to increased $\mathrm{P}_{\mathrm{i}}$ availability (Fig. 2).

\subsection{Evidence supporting $C$-driven $P_{0}$ mineralization}

While $\mathrm{P}_{\mathrm{o}}$ compounds are a $\mathrm{C}$ source for microbes, there is limited to no evidence of direct $\mathrm{P}_{\mathrm{o}}$ assimilation by soil microbes (George et al., 2017). A lack of evidence does not exclude the possibility of phosphorylated compound uptake, but dephosphorylation either facilitates or is a requisite step in the acquisition of $\mathrm{C}$ from $\mathrm{P}_{\mathrm{o}}$. Evidence for $\mathrm{C}$-driven $\mathrm{P}_{\mathrm{O}}$ mineralization comes from studies showing the coupling of $\mathrm{P}_{\mathrm{o}}$ mineralization and SOM decomposition (Dalal, 1979; Gressel et al., 1996; Moller et al., 2000). In dual-labeling experiments with ${ }^{33} \mathrm{P}$ and ${ }^{14} \mathrm{C}$, the preferential microbial uptake of $\mathrm{C}$ from labeled glucose phosphate was greater than that of P, even under C saturation (Spohn and Kuzyakov, 2013; Heuck et al., 2015). Fransson and Jones (2007) found that organic compounds like adenosine were preferentially mineralized over their phosphorylated counterparts (AMP, ADP, and ATP), and that low phosphatase activity may limit the use of phosphorylated compounds at elevated $\mathrm{P}_{\mathrm{o}}$ concentrations. Accordingly, the activity of the C-mineralizing enzyme $\beta$-glucosidase explained $41 \%$ to $69 \%$ of the variation in phosphatase activity (Wang et al., 2016), indicating that the two groups of mineralization enzymes can be closely related (Sinsabaugh et al., 2009). 


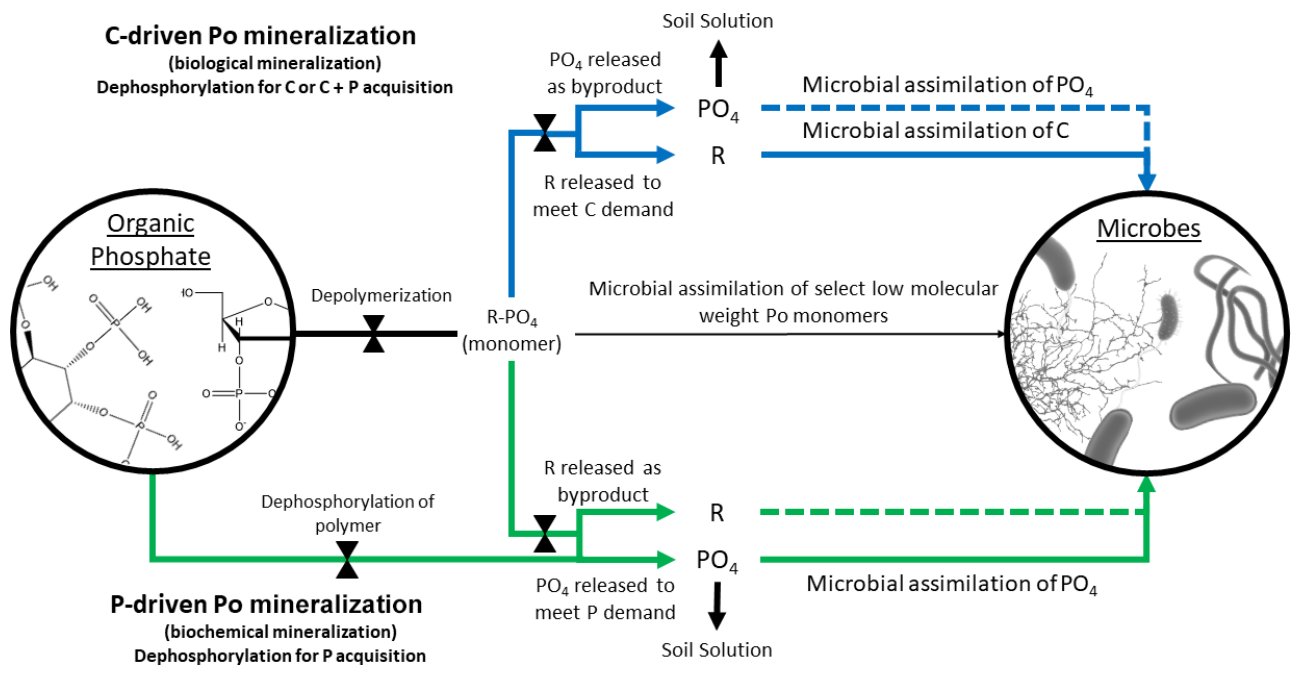

Figure 2. Conceptual diagram of $\mathrm{C}$ - and $\mathrm{P}$-driven $\mathrm{P}_{\mathrm{O}}$ mineralization. Because microorganisms can only directly uptake specific types of orthophosphate ester $\left(\mathrm{P}_{\mathrm{O}}\right)$ monomers (thin middle black arrow), the accessibility of $\mathrm{P}_{\mathrm{O}}$ is controlled by the action of phosphatase enzymes (indicated by bow ties). The blue arrows represent $\mathrm{C}$-driven $\mathrm{P}_{\mathrm{O}}$ mineralization, whereby the organic compound is mineralized for $\mathrm{C}$ acquisition and, depending on $\mathrm{P}$ demand, for $\mathrm{P}$ acquisition (immobilization; indicated by dotted blue line). $\mathrm{P}$ that is unused by microbes is left in the soil solution. The green arrows represent $\mathrm{P}$-driven $\mathrm{P}_{\mathrm{O}}$ mineralization, whereby $\mathrm{PO}_{4}$ is hydrolyzed from the $\mathrm{P}_{\mathrm{O}}$ compound and assimilated without further $\mathrm{C}$ processing (unless the $\mathrm{C}$ is available for uptake and is needed and is circumstantially assimilated; indicated by green dotted line).

\subsection{The coexistence of $C$-driven and $P$-driven $P_{0}$ mineralization}

It may only be on the extremes of a continuum of $\mathrm{C}$ or $\mathrm{P}$ limitation where $\mathrm{C}$ - or $\mathrm{P}$-driven $\mathrm{P}_{\mathrm{O}}$ mineralization dominates (Fig. 3), with the coexistence of these mechanisms under colimiting conditions. In a temperate P-limited system, Heuck et al. (2015) found that $\mathrm{C}$-driven $\mathrm{P}_{\mathrm{o}}$ mineralization dominated, likely due to concurrent $\mathrm{C}$-limitation that drove mineralization. Similarly, different microsites in the soil can be Por C-limited, further complicating data interpretation when analyses are done in soil volumes that cannot distinguish processes at microscales.

Strict P-driven mineralization may not apply to soils and microbial communities that are $\mathrm{C}$-limited, but soils and microbes are not always C-limited (Zechmeister-Boltenstern et al., 2015), particularly in tropical systems that can have significant P limitations (Camenzind et al., 2018). In highly weathered soils, the strong $\mathrm{P}_{\mathrm{i}}$ fixation potential and overall low $\mathrm{P}_{\mathrm{i}}$ makes $\mathrm{P}_{\mathrm{o}}$ the dominant $\mathrm{P}$ source in the soil (McDowell et al., 2007; Vincent et al., 2010); thus, P-scavenging P acquisition strategies may be more prevalent. Soil type does not completely explain the dominance of $\mathrm{P}$-driven $\mathrm{P}_{\mathrm{o}}$ mineralization, as it may also depend on $\mathrm{P}_{\mathrm{o}}$ speciation. Vincent et al. (2010) observed that litter manipulations did not impact soil $\mathrm{C}: \mathrm{N}: \mathrm{P}$ stoichiometry in a lowland tropical forest, indicating a nondiscriminating mineralization behavior. As noted by these authors, the observed absence of inositol phosphates, which are very recalcitrant $P_{o}$ compounds, may have reduced the prevalence of P-driven mineralization.
A depletion in inositol phosphate, as seen in other studies (McDowell et al., 2007), may have been caused by earlier P-driven $\mathrm{P}_{\mathrm{o}}$ mineralization (McDowell et al., 2007; Turner et al., 2007). Organic substrates of varying composition and their varying propensity to specific mineralization pathways may influence $\mathrm{P}$ stoichiometry and $\mathrm{P}_{\mathrm{o}}$ mineralization.

\subsection{Synthesis}

Measuring and differentiating $\mathrm{P}_{\mathrm{o}}$ mineralization pathways is an important step for modeling $\mathrm{P}$ biogeochemistry. Some land surface and catchment models simulate $\mathrm{P}$-driven $\mathrm{P}_{\mathrm{o}}$ mineralization (Wang et al., 2010; Goll et al., 2012, 2017; Davies et al., 2016; Yu et al., 2018, 2020; Thum et al., 2019; Zhu et al., 2019), but they are parameterized on limited observations (Reed et al., 2015; Thum et al., 2019) that are measured using unrepresentative or inaccurate methods. The first of these methodological limitations is the inaccuracy of Pdriven mineralization measurements. It is difficult to quantify $\mathrm{P}$-driven relative to $\mathrm{C}$-driven mineralization with current assays (Oehl et al., 2004; Achat et al., 2016), particularly as phosphatase may play a role in both P- and Cdriven mineralization, complicating the use of phosphatase assays. Secondly, phosphatase enzyme assays are used as a proxy for P-driven mineralization (Goll et al., 2017), but the assays often overestimate real phosphatase activity and cannot be conducted in the field (Goll et al., 2012). Lastly, the mechanisms of phosphatase production and the relationship between phosphatase activity and mineralization are difficult to measure and are therefore poorly understood and 


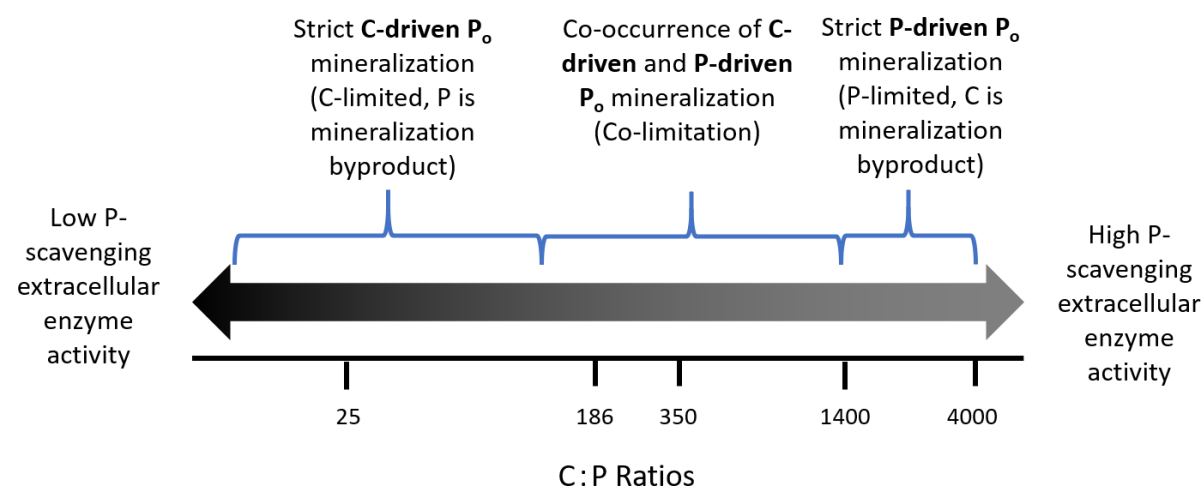

Figure 3. Hypothesis of stoichiometric controls on C-driven and $\mathrm{P}$-driven $\mathrm{P}_{\mathrm{O}}$ mineralization. The $\log$-scaled numbers are $\mathrm{C}: \mathrm{P}$ ratios taken from the literature that include stoichiometry of microbes, litter, soil, and critical ratios. The brackets represent where biological or biochemical mineralization may begin to dominate. The values in the figures are as follows: 25 microbial biomass $\mathrm{C}: \mathrm{P}$ ratio -1 lower bound of study range (Capek et al., 2016); 186 soil C : P ratio - global average (Cleveland et al., 2007); 350 microbial biomass C : P ratio - upper bound of study range (Capek et al., 2016); 1400 threshold elemental ratio (Heuck et al., 2016); and 4000 decomposition stop point (Zechmeister-Boltenstern et al., 2015).

not explicitly simulated in models (Oehl et al., 2004; Achat et al., 2016). Schimel and Weintraub (2003) took an enzymemediated approach to SOM decomposition and mineralization, but applying this approach to $\mathrm{P}_{\mathrm{o}}$ decomposition and mineralization would require more accurate phosphatase activity assays and an ability to differentiate between extracellular and intracellular soil phosphatase. Better representing the $\mathrm{P}$ cycle in models is less a question of calibration and more a need to improve our fundamental understanding of $\mathrm{P}$ and C-driven $\mathrm{P}_{\mathrm{O}}$ mineralization. However, further investigation of $\mathrm{P}_{0}$ mineralization is hindered by the nature of $\mathrm{P}$ isotope chemistry, accessibility of appropriate methods, and currently held assumptions of the two pathways.

The coregulation of $\mathrm{P}_{\mathrm{o}}$ mineralization by substrate properties and by plant and microbial P-demand needs to be clarified. Developing methods to measure real instead of potential phosphatase activity will allow a more accurate estimation of $\mathrm{P}_{\mathrm{o}}$ mineralization from actively produced phosphatase enzymes (Nannipieri et al., 2011; Bünemann, 2015). This will reduce the overestimation problem of current in vitro phosphatase enzyme assays (Nannipieri et al., 2011; Spohn et al., 2013), enabling a more accurate parameterization of models based on the explicit simulation of phosphatase activity.

Microbial or plant demand for $\mathrm{P}$ can also regulate phosphatase production, and the properties of $\mathrm{P}_{\mathrm{O}}$ would determine the effectiveness of these phosphatases. A typical approach in modeling is determining the maximum turnover rate of a given pool, which in this case can be equated to the rate of $\mathrm{P}_{\mathrm{o}}$ mineralization in systems that are flooded with phosphatase. This rate can be reduced by the actual phosphatase activity that, in turn, would depend on a calculated demand from microbes and plants. Although not simulating the relative plant and microbe phosphatase activity in this manner, Yu et al. (2020) simulated $\mathrm{P}_{\mathrm{o}}$ mineralization by combining the soil enzyme allocation model (SEAM; Wutzler et al., 2017) and the equilibrium chemistry approximation (ECA; Tang and Riley, 2013) to estimate the allocation of enzymes between $P_{o}$ sources and the subsequent microbial-plant uptake.

$\mathrm{P}$ turnover and the link with organic $\mathrm{C}$ mineralization can be studied with ${ }^{32} \mathrm{P}$ and ${ }^{33} \mathrm{P}$ isotope dilution (Frossard et al., 2011) and ${ }^{18} \mathrm{O}-\mathrm{P}$ tracing to obtain mineralization rates alongside enzyme activity assays. ${ }^{18} \mathrm{O}$ isotope $\mathrm{P}$-tracing techniques have been used as a safe alternative to radioisotopes in tracing inorganic phosphate (Tamburini et al., 2010, 2014), and recent methods have demonstrated the efficacy of ${ }^{18} \mathrm{O}$ tracing of organic phosphate (Liang and Blake, 2006; Tamburini et al., 2018). However, $\mathrm{P}_{\mathrm{o}}$ tracing methods using oxygen isotopes are in their infancy and have not been applied outside of a proof of concept. Experiments employing ${ }^{18} \mathrm{O}$ tracing techniques for both $\mathrm{P}_{\mathrm{i}}$ and $\mathrm{P}_{\mathrm{o}}$ must be conducted on a wider range of soils (Nannipieri et al., 2011). Further employment of these methods could help discern biological processes and the turnover of phosphate in natural abundance (Roberts et al., 2015) and tracer studies (Joshi et al., 2016). They can also be used for P source characterization (Zohar et al., 2010; Frossard et al., 2011).

Discriminating the activity of microorganisms from those of stabilized enzymes is also tractable (Turner and Joseph Wright, 2014). One way would be to measure the expression of phosphatase genes in plants and microorganisms as a response to changes in $\mathrm{P}$ availability. A characterization of microbial or plant responsiveness to shifts in $\mathrm{P}$ availability would further help to integrate $\mathrm{P}$-driven $\mathrm{P}_{\mathrm{o}}$ mineralization into models, as it is determined by specific environmental and biological conditions. This requires further work to identify conditions that lead to changes in gene expression (Grafe et al., 2018). 


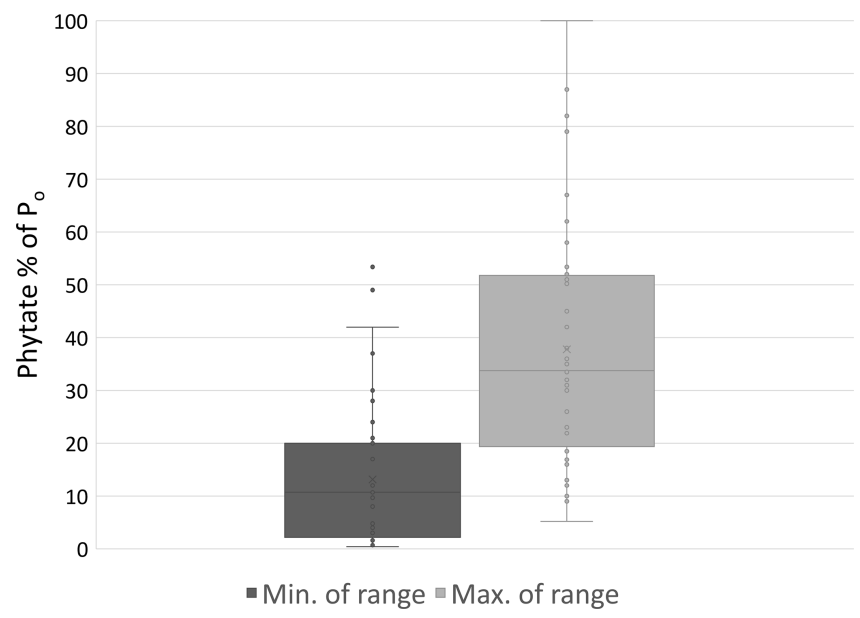

Figure 4. Minimum and maximum percent of $P_{O}$ comprised of phytate observed in a variety of natural and agricultural systems $(n=41)$. Sources: Giles (2014) and Turner $(2002,2007)$.

\section{Phytate dynamics and the unpredictability of $P$ stoichiometry}

\subsection{Phytate}

$\mathrm{P}_{\mathrm{o}}$ species differ in abundance due to their variable affinity for mineral or SOM sorption and recalcitrance to mineralization. Commonly, the most prevalent $\mathrm{P}_{\mathrm{o}}$ forms in soil are inositol phosphates consisting of six carbon rings with one to six phosphate groups. Myo-inositol hexakisphosphate, also known as phytate in its salt form, is the most abundant inositol phosphate and has six P groups (Harrison, 1987; Turner et al., 2002). Phytate is stabilized in the soil through ligand exchange, formation of metal phosphate bridges to SOM, and precipitation as insoluble salts (Celi et al., 1999; Jørgensen et al., 2015). The phosphate groups bind to mineral surfaces by ligand exchange with hydroxyls and to mineral and SOM cationic surfaces via electrostatic binding (Celi et al., 1999; Arai and Sparks, 2007; Jørgensen et al., 2015). Phytate's tendency to bind to the soil phase contributes to its abundance and recalcitrance in mineralization (Anderson et al., 1974; Turner et al., 2002; Berg and Joern, 2006). A majority, from $29 \%$ to $65 \%$ and even up to $90 \%$, of soil $P_{o}$ can be phytate (Harrison, 1987; Turner et al., 2002), but this can vary substantially depending on factors that are not fully understood (Fig. 4).

A thorough review of inositol phosphates is found in Turner (2007), but relevant information and new findings will be covered here. Phytate is prevalently stored in grain (and pollen, which is a small pool) but is also found in roots, crowns, and leaves, potentially as a transient storage compound (Campbell et al., 1991; Hubel and Beck, 1996). Turner (2007) noted that, despite prevalent research on phytate and other soil inositol phosphates, their abundance varies widely and often unpredictably. As described by McGill and Cole
(1981) and later supported by Shang et al. (1990), phytate sorption dynamics are similar to that of orthophosphate and are partially controlled by similar factors (sorption capacity; Fe and Al oxide content; Yan et al., 2014). The abundance of phytate measured in agricultural systems is attributed to their recalcitrance and stability through sorption and precipitation (Yan et al., 2014) and prevalence in manures (particularly nonruminants) and animal feeds (Sun and Jaisi, 2018).

\subsubsection{Controls on phytate mineralization}

The solubility and lability of phytate compounds, the principal controls on phytate mineralization, and the extent and efficacy of their mineralization by plants remain unclear (Richardson et al., 2000; Gerke, 2015a). We do know that phytate mineralization is a two-step process whereby phytate is first solubilized and made accessible to phytatehydrolyzing enzymes called phytases (Mullaney and Ullah, 2007; Gerke, 2015a, b). In this review, the term phytase is used rather than the more general term of phytate-degrading enzymes, which refers to any enzyme in vivo or in vitro that can hydrolyze phosphate from phytate (Greiner, 2007). Because this review focuses on the in vivo processes, the term phytase is preferred.

The two principal controls on phytate mineralization are the production of phytase and the solubility of phytate, but their relative influence on mineralization is not fully understood. Phytate is expected to undergo hydrolysis in the soil solution (Ognalaga et al., 1994), but for that to happen, it must first be solubilized from the soil phase through abiotic or biotic processes (Gerke, 2015a, b). Akin to other organic phosphates, biotically mediated dissolution of phytate can be facilitated by organic anions that chelate $\mathrm{Fe}, \mathrm{Al}$, or $\mathrm{Ca}$ (Tang et al., 2006). While solubilization is thought to be the limiting step in the hydrolysis of phytate (Greaves and Webley, 1969; Lung and Lim, 2006; Patel et al., 2010; Gerke, 2015a), other studies have shown that hydrolysis and phytase production are also limiting steps (Findenegg and Nelemans, 1993; Hayes et al., 2000; Richardson et al., 2001; George et al., 2004).

Microorganisms are key regulators of phytate mineralization. They produce both phytate-solubilizing organic acids (Richardson and Simpson, 2011) and multiple classes of phytate mineralizing enzymes (Hill and Richardson, 2007; Mullaney and Ullah, 2007). Soil microbial communities appear to be crucial agents in increasing phytate availability for plant acquisition (Richardson and Simpson, 2011). The extent to which plants themselves control phytate mineralization outside of in vitro studies or genetic modification is less clear.

\subsubsection{Plant-mediated phytate mineralization}

A limited number of reports indicate that some plant species can secrete phytase (Li et al., 1997; Belinque et al., 2015). This is likely a response to limited $P_{i}$ availability (Tarafdar 
and Claassen, 2003) and would be a prime example of Pdriven $\mathrm{P}_{\mathrm{O}}$ mineralization with phytate as the substrate. Steffens et al. (2010) demonstrated plant-mediated phytate mineralization in a growth chamber experiment with negligible microbial activity. While studies of this nature are scarce, Belinque et al. (2015) found that oilseed rape, sunflower, and soybean grown under sterile conditions could use phytate as a P source, and that microbial inoculation had a minimal effect on overall plant acquisition of phytate $P$.

Contrary to these findings, other authors have reported that phytate mineralization and the subsequent uptake of phytatederived $\mathrm{P}$ by plants is minimal or absent (Findenegg and Nelemans, 1993; Richardson et al., 2000, 2001; Lung and Lim, 2006) or that detected phytase was plant-derived but involved in intracellular root phytate regulation rather than extracellular phytate scavenging (Hubel and Beck, 1996; Asmar, 1997; Richardson et al., 2000). If extracellular phytase release from plants is truly minimal or absent, effective plant use of soil phytate would depend heavily on phytaseproducing microorganisms (Richardson et al., 2000; Idriss et al., 2002) or the expression of microbial phytase genes in transgenic plants (Richardson et al., 2001; Lung et al., 2005; Giles et al., 2017). Furthermore, phytate use may still be limited by either microbial exoenzyme production (Findenegg and Nelemans, 1993) or phytate accessibility (Gerke, 2015a, b).

\subsubsection{Variable abundance and mineralization rates of soil phytate}

There are exceptions that do not fit, or question, a neat pattern of phytate stabilization and retention in soil. Contrary to the widespread abundance of phytate often attributed to its recalcitrance to mineralization, rapid phytate mineralization has been observed in noncalcareous (Dou et al., 2009) and calcareous soils (Leytem et al., 2006; Doolette et al., 2010). Possible explanations to rapid mineralization are that certain soil conditions increase phytate solubility or that some phytates are inherently more soluble or susceptible to hydrolysis, depending on interactions with specific minerals or SOM.

As explained by Turner and Blackwell (2013), unless the soil solution of a calcareous soil has excess dissolved $\mathrm{Ca}^{2+}$, $\mathrm{Ca}$ phytate is slightly more soluble than $\mathrm{Fe}$ and $\mathrm{Al}$ phytates (Jackman and Black, 1951). Furthermore, Ca phytate mineralizes more rapidly than insoluble $\mathrm{Fe}$ - or $\mathrm{Al}$-associated phytates (Greenwood and Lewis, 1977; Quiquampoix and Mousain, 2005; Tang et al., 2006), even at a pH 6-8 (Greaves and Webley, 1969)

Working in a noncalcareous soil, Dou et al. (2009) found a lack of phytate accumulation and presumed rapid mineralization. In this case, although $\mathrm{Al}$ and $\mathrm{Fe}$ contents and fixation capacity may have been high, the soil was likely saturated with $\mathrm{C}_{\mathrm{o}}$ from previous manure applications. This would have increased the solubilization of phytate and contributed to its observed rapid mineralization, a subject discussed further below in Sect. 4, organic P and C saturation.

\subsubsection{Synthesis}

Although both plants and microbes can release phytase and phytate-solubilizing organic acids (Richardson et al., 2009b), microbes indirectly facilitate phytate acquisition (Richardson et al., 2001, 2009a), likely due to greater production of phytate solubilization or mineralization enzymes. It is therefore necessary to further investigate the interplay between microbes and plants, particularly in vivo, where experimentation is limited (Giles and Cade-Menun, 2014).

Although phytate makes up a large percentage of soil $\mathrm{P}_{\mathrm{o}}$ in many soils, its dynamics are not explicitly simulated in models. Instead of constructing general pools with presumed $\mathrm{P}_{\mathrm{o}}$ turnover rates, specific forms of $\mathrm{C}$ and $\mathrm{P}$ should be identified and their roles in the turnover of $\mathrm{P}_{\mathrm{o}}$ investigated (Arenberg and Arai, 2019) with the ultimate goal of incorporating phytate-specific pools in models, such as those depicted in Fig. 5. However, this will require elucidating the actual phytate abundance, as it is likely overestimated due to limitations in phytate analysis (Smernik and Dougherty, 2007; Doolette et al., 2011).

Integrating phytate pools into models would be facilitated by further research on the sorption of phytate and its mobility (Gerke, 2015b), the complementary effects of organic acid and phytase exudation from both plants and microbes on phytate depletion (Giles et al., 2017), and the observations of rapid phytate mineralization (Doolette et al., 2010) and reduced stabilization (Dou et al., 2009) resulting in variable phytate abundance. Coupling isotope tracing and ${ }^{31} \mathrm{P}$ nuclear magnetic resonance (NMR) spectroscopy techniques will also provide important insights into the fate of $\mathrm{P}_{\mathrm{O}}$ compounds like phytate (Giles and Cade-Menun, 2014; Tamburini et al., 2018). However, further studies on plant and microbial strategies for improving phytate acquisition must also be conducted at the field scale (Giles and Cade-Menun, 2014). There is also a need to eliminate or reduce the ambiguities in ${ }^{31} \mathrm{P}$ NMR techniques when characterizing or quantifying $\mathrm{P}_{\mathrm{o}}$, a topic covered in Kruse et al. (2015). The lack of clarity surrounding the different mineralization pathways, the varying recalcitrance of $P_{0}$ species, or a combination of the two may contribute to the observed wide global variation in $\mathrm{C}: \mathrm{P}$ or $\mathrm{N}: \mathrm{P}$ stoichiometry (Vincent et al., 2010; Tipping et al., 2016).

\subsection{Stoichiometry}

The flux of nutrients between soil and organisms can be modeled by tying $\mathrm{C}$ fluxes to $\mathrm{C}: \mathrm{N}: \mathrm{P}$ stoichiometry - if it is known and predictable. Knowledge of $\mathrm{C}: \mathrm{N}$ ratios has enabled accurate modeling of $\mathrm{N}$ limitation and mineralizationimmobilization dynamics (White et al., 2014). This modeling success can be attributed to the tight coupling of $\mathrm{C}$ and 


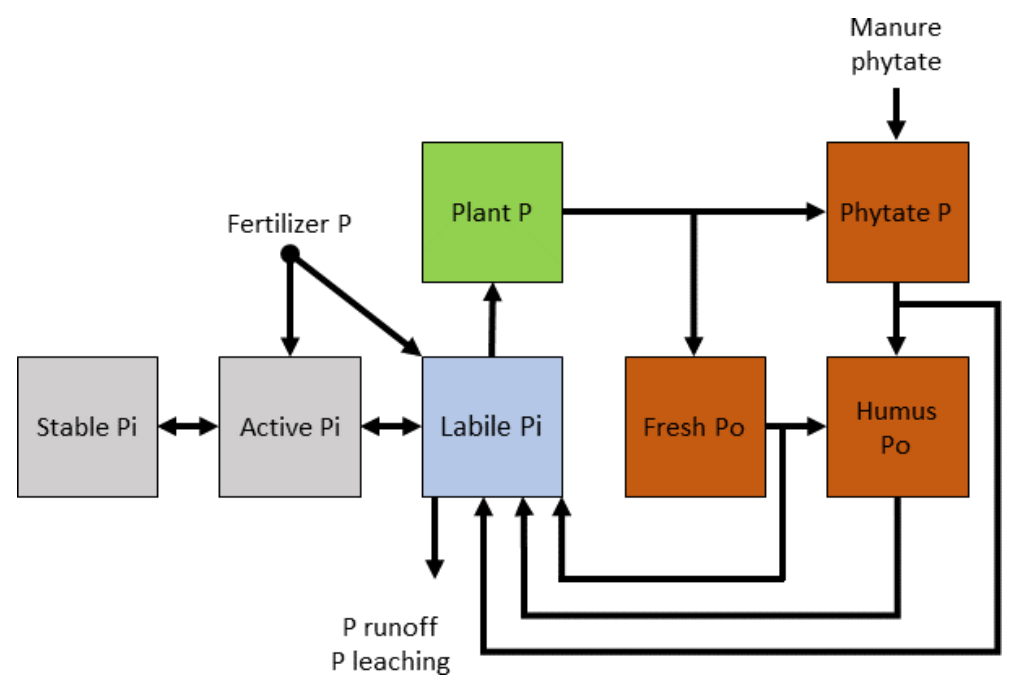

Figure 5. Simple conceptual diagram for modeling inorganic and organic phosphorus cycling, which includes an explicit phytate pool.

$\mathrm{N}$ in soils across ecosystems, which is largely because organic N makes up $95 \%$ of soil N (Duxbury et al., 1989; Kirkby et al., 2011; Yang and Post, 2011). Soil C : P and $\mathrm{N}: \mathrm{P}$ ratios are currently used in simulation models, but $\mathrm{P}_{\mathrm{i}}$ and $\mathrm{P}_{\mathrm{o}}$ are often poorly correlated with soil $\mathrm{C}$ or $\mathrm{N}$ content (Yang and Post, 2011; Hartman and Richardson, 2013; Tipping et al., 2016; Zhou et al., 2018). Variation in soil C : P ratios, flexible microbial stoichiometry or not strictly homeostatic behavior (Hartman and Richardson, 2013), and unpredictable microbial critical ratios (CRs) contribute to model uncertainty. Variability in soil and microbial stoichiometry derive from methodological or analytical discrepancies (Kirkby et al., 2011), edaphic and ecosystem properties, and microorganism-specific characteristics (Mooshammer et al., 2014; Čapek et al., 2016), all of which must be considered when modeling plant litter and SOM decomposition.

\subsubsection{Soil stoichiometry}

The use of $\mathrm{P}_{\mathrm{o}}, \mathrm{P}_{\mathrm{i}}$, or $\mathrm{P}_{\mathrm{t}}($ total $\mathrm{P})$ in stoichiometry measurements requires clarification, as methodological differences (Kirkby et al., 2011) can confuse matters. Including $P_{i}$ in $C: P_{t}$ ratios introduces more variability in relating $C$ and $P$ because $\mathrm{P}_{\mathrm{i}}$ can cycle independently of $\mathrm{C}$ and $\mathrm{N}$. The $\mathrm{C}: \mathrm{P}_{\mathrm{o}}$ ratio, where $\mathrm{C}$ only includes organic $\mathrm{C}$, may better represent $\mathrm{P}_{\mathrm{o}}$ stoichiometry in the soil, but it too can vary widely, depending on the plant and microbial communities, ecosystem, and management (Fig. 6; Hartman and Richardson, 2013; Mooshammer et al., 2014; Čapek et al., 2016, 2018; Tipping et al., 2016). The decoupling of $C: \mathrm{P}_{t}$ and $\mathrm{N}: \mathrm{P}_{t}$ is also seen as the soil weathers (Yang and Post, 2011), where $P_{o}$ becomes the predominant contributor to $\mathrm{P}$ fertility (Yang and Post, 2011; Cleveland et al., 2013; Bünemann, 2015), and nutrient acquisition strategies shift from physiochemical $P_{i}$ acquisition to closed $P_{o}$ cycling (Lang et al., 2017). Another possibility for this stoichiometric decoupling is the varying abundance of specific $\mathrm{P}_{\mathrm{o}}$ forms between systems (Kirkby et al., 2011). Because the $C: P$ ratio of phytate is 1 , shifting or variable phytate abundance would reflect in the soil $\mathrm{C}: \mathrm{P}$ stoichiometry. A depletion of mineral $\mathrm{P}_{\mathrm{i}}$, an absence of a strong $\mathrm{C}$ limitation, changes in the abundance of certain $\mathrm{P}_{\mathrm{O}}$ forms, or a potential shift to $\mathrm{P}$-driven $\mathrm{P}_{\mathrm{O}}$ mineralization processes may explain this decoupling.

\subsubsection{Plant and microbial stoichiometry}

The variability seen in soil $\mathrm{C}: \mathrm{P}$ stoichiometry is also seen in $\mathrm{C}: \mathrm{P}$ ratios of plants and microbes across and within ecosystems (Cleveland and Liptzin, 2007; Hartman and Richardson, 2013; Xu et al., 2013; Čapek et al., 2016). Plant stoichiometry is an important control on the flux of soil nutrients as it influences the decomposition activity of microbes (Manzoni et al., 2008, 2010). Microbes are the principal decomposers of litter and SOM and, thus, a major driver of $\mathrm{P}$ transformation in the soil (Zechmeister-Boltenstern et al., 2015), which is thought to be controlled by their own stoichiometry (Hall et al., 2011).

Microbial stoichiometry is more constrained than that of plants (Xu et al., 2013; Arenberg and Arai, 2019) and is often purported to be strictly homeostatic (Cleveland and Liptzin, 2007). Although microbial stoichiometry is roughly constrained on the global level, microbes at the population, ecosystem, or community scale may not be strictly homeostatic, as found in aquatic systems (Cotner et al., 2010). Soil microbes may also display the same level of stoichiometric flexibility (Hartman and Richardson, 2013), varying due to population-size-dependent scaling, habitat and ecosystem differences, or shifts in microbial community composition (Hartman and Richardson, 2013; Mooshammer et al., 2014; Čapek et al., 2016). 

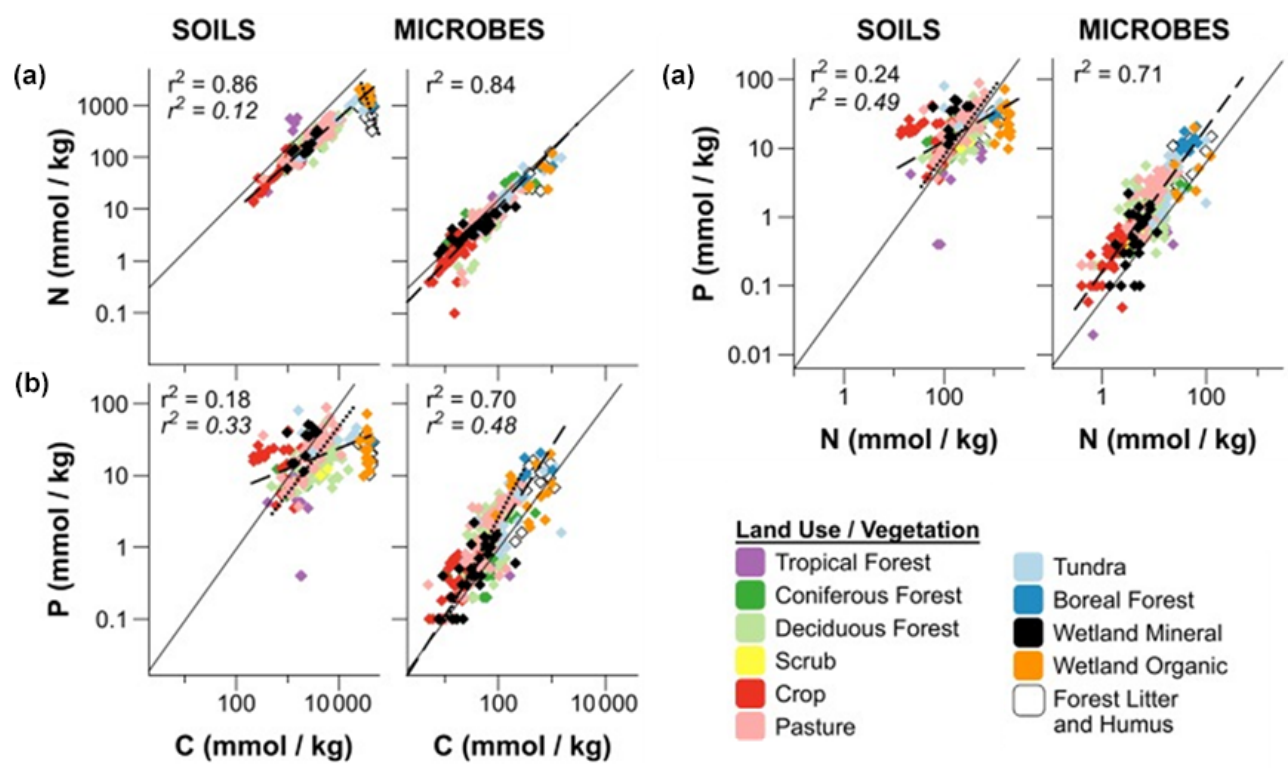

Figure 6. Regressions of $\mathrm{C}: \mathrm{N}(\mathbf{a}), \mathrm{C}: \mathrm{P}(\mathbf{b})$, and $\mathrm{N}: \mathrm{P}(\mathbf{c})$ ratios in soils and microbial biomass using a $\log _{10}$ transformation. The dashed lines (standard font $\mathrm{r}^{2}$ ) are regressions of soil or microbial biomass stoichiometry for all land use or vegetation types that do not differ significantly. The dashed lines (italicized font $r^{2}$ ) are regressions of stoichiometries that differ significantly from the other land use or vegetation types. For $\mathrm{C}: \mathrm{N}(\mathbf{a})$, these land use or vegetation types were wetland organic, boreal forest, and humic horizons. For $\mathrm{C}: \mathrm{P}(\mathbf{b})$ and $\mathrm{N}: \mathrm{P}(\mathbf{c})$ the forest and pasture soils differed significantly from the other land use or vegetation types. The solid lines represent the Redfield (1958) ratio. Modified from Hartman and Richardson (2013).

Accounting for this variability in models is further complicated by the difficulties in calculating microbial nutrient demand, governed by the ratio of $\mathrm{C}: \mathrm{P}$ at which microbes shift between mineralization and immobilization (Manzoni et al., 2010; Hartman and Richardson, 2013). This critical ratio $(\mathrm{CR})$ is often predicted using direct measurements of microbial biomass $\mathrm{C}: \mathrm{P}$, which itself is poorly correlated to actual microbial nutrient requirements (Čapek et al., 2018). This is in part because microbes can store $\mathrm{P}$ in the form of polyphosphates (up to $30 \%$ of their dry weight; Deinema et al., 1985; Kulaev et al., 1999), which reflects an indirect translation between $\mathrm{C}: \mathrm{P}$ ratios and demand (Čapek et al., 2016, 2018).

The microbial $\mathrm{C}: \mathrm{P}_{\mathrm{CR}}$ is an important factor to model because mineralized or immobilized substrates provide or restrict P to plants, respectively. Čapek et al. (2016) attempted to predict the $\mathrm{C}: \mathrm{P}_{\mathrm{CR}}$ using microbial biomass stoichiometry and soil $\mathrm{P}$ measurements but were unsuccessful, likely because $\mathrm{C}: \mathrm{P}_{\mathrm{CR}}$ is not solely dependent on biomass $\mathrm{C}: \mathrm{P}$ but on various edaphic and community-specific factors as well. This may explain why previous studies have failed to see a strong relationship between $\mathrm{P}_{0}$ mineralization and $\mathrm{C}: \mathrm{P}$ ratios of SOM (Enwezor, 1967, 1976; McLaughlin et al., 2011). Using a fixed microbial $\mathrm{C}: \mathrm{P}_{\mathrm{CR}}$ may not capture the observed variability (Hartman and Richardson, 2013; Čapek et al., 2016), but implementing a flexible $\mathrm{C}: \mathrm{P}_{\mathrm{CR}}$ in a model is not yet possible due to the ratio's unpredictability (Čapek et al., 2016). However, one can tentatively assume that microbial commu- nities adjust their $\mathrm{P}$ requirements by increasing $\mathrm{C}: \mathrm{P}_{\mathrm{CR}}$ as $\mathrm{P}$ becomes more limiting. The degree of $\mathrm{P}$ limitation depends in part on $\mathrm{N}$ availability because, to sustain $\mathrm{P}$-driven $\mathrm{P}_{\mathrm{o}}$ mineralization, microbes need $\mathrm{N}$ sources to sustain phosphatase enzyme production (Olander and Vitousek, 2000; Houlton et al., 2008). Supporting this view, Margalef et al. (2017) found that total $\mathrm{N}$ content was strongly correlated to phosphatase activity across global soil measurements.

\subsubsection{Synthesis}

One of the difficulties in modeling soil $\mathrm{P}$ dynamics is predicting the $\mathrm{C}: \mathrm{N}: \mathrm{P}$ stoichiometry of plants, microbes, and SOM. This is due to the many, often interacting, sources of variation in $\mathrm{P}$ stoichiometry, such as habitat, edaphic properties, soil C quality, microbial population dynamics, climate, season, and disturbance or management (Cleveland et al., 2004; Aponte et al., 2010; Hartman and Richardson, 2013; Čapek et al., 2016). Establishing better relationships between these sources of variability and observed nutrient stoichiometry and implementing a consistent measurement protocol for $\mathrm{C}: \mathrm{P}$ ratios will help future data collection and consolidation efforts.

The variability in $\mathrm{C}: \mathrm{P}_{\mathrm{CR}}$ or the microbial and $\mathrm{C}: \mathrm{P}$ ratios presented in Fig. 6 makes it difficult, but not intractable, to set constraints on $\mathrm{P}$ cycling models. Many models assume fixed stoichiometry for the soil or soil pools (Kemanian et al., 2011), which may only be applicable to certain soil systems. 
Using fixed P stoichiometry to model P biogeochemistry may not capture $\mathrm{P}$ dynamics across ecosystems, but implementing variable $\mathrm{C}: \mathrm{P}$ ratios, like those in the CENTURY model, requires improved parameterization and understanding of the factors that control $\mathrm{C}: \mathrm{P}$ ratios. Clarifying the role of phytates may simplify this task because phytate's $\mathrm{C}: \mathrm{P}=1$ is a ratio well below the $\mathrm{C}: \mathrm{P}_{\mathrm{CR}}$ of any organism. It is also necessary to elucidate the mechanisms of $\mathrm{P}$-driven $\mathrm{P}_{\mathrm{O}}$ mineralization because, first, CRs do not reflect $\mathrm{P}$ dynamics in systems dominated by such $\mathrm{P}_{\mathrm{o}}$ mineralization pathways (McLaughlin et al., 2011), and second, $\mathrm{P}$-driven $\mathrm{P}_{\mathrm{o}}$ mineralization can drive the decoupling of $\mathrm{P}$ mineralization from SOM decomposition (Goll et al., 2012).

Including an explicit microbial pool that accounts for physiological and community dynamics (Allison, 2012; Wieder et al., 2014) when modeling the $\mathrm{P}$ cycle will better represent microbial adaptation to changing resource stoichiometry. However, further research into communityspecific drivers of microbial stoichiometry is needed, such as accounting for differences in the $\mathrm{P}$ acquisition strategies of bacteria and fungi (Waring et al., 2013). Representing this in models could be as simple as accounting for bacterial and fungal $\mathrm{C}: \mathrm{P}$ or biomass ratios, akin to the approach of Waring et al. (2013) for $\mathrm{C}$ and $\mathrm{N}$ cycling, or a more complex, trait-based approach (Allison, 2012; Wieder et al., 2014).

\section{Organic $P$ and $C$ saturation}

$\mathrm{P}$ saturation refers to the level of soil $\mathrm{P}$, typically inorganic, in relation to the measured sorption capacity. $\mathrm{P}$ saturation is often expressed as the degree of $\mathrm{P}$ saturation (DPS), which is used as an environmental risk indicator of potential dissolved P losses (Breeuwsma et al., 1995). Soils with DPS levels that surpass a change point (hereafter referred to as threshold DPS) exhibit significant increases in dissolved $\mathrm{P}$ transport due to the saturation of high-energy sorption sites and reduction in $\mathrm{P}_{\mathrm{i}}$ retention strength (Hooda et al., 2000; Maguire and Sims, 2002; Butler and Coale, 2005; Abdala et al., 2012). This threshold DPS generally occurs between $25 \%$ and $56 \%$ saturation, depending on the soil (Maguire and Sims, 2002).

Difficulties in narrowing the range of threshold DPS or creating a simple predictive framework can be partially attributed to the ambiguous treatment of $\mathrm{C}_{\mathrm{o}}$ saturation and $\mathrm{P}_{\mathrm{o}}$ abundance in DPS measurements. One such DPS measurement uses oxalate or Mehlich 3 extractions to obtain the molar ratio of extractable $\mathrm{P}$ to the sorption maximum determined by extractable $\mathrm{Al}$ and Fe (van der Zee and van Riemsdijk, 1988; Kleinman and Sharpley, 2002). This method ignores the soil $\mathrm{C}_{\mathrm{o}}$ content which, if high enough, can reduce the physically obtainable $\mathrm{P}$ saturation potential of a soil (Table 1; Fig. 7a) and influence the rate of $\mathrm{P}_{\mathrm{o}}$ mineralization (Fig. 7b). Furthermore, certain extractants and analytical methods do not target $\mathrm{P}_{\mathrm{o}}$ (e.g., Mehlich 3 extraction, $\mathrm{P}_{\mathrm{i}}$ sorption isotherms, and spectrophotometric methods), leading to an underestimation of the actual total P DPS (Table 1 ; Fig. 7c). The extent to which DPS is affected by $P_{0}$ and $C_{0}$ depends on the relative concentrations of $P_{i}$ and $P_{O}$, the form of $\mathrm{P}_{\mathrm{O}}$ and its sorption potential, and the interacting sorption relationships between $\mathrm{P}_{\mathrm{O}}, \mathrm{P}_{\mathrm{i}}$, and dissolved organic compounds from the breakdown of SOM.

Because $\mathrm{P}_{\mathrm{O}}$ turnover and mineralization is partially controlled by its solubility (Greaves and Webley, 1969; Grafe et al., 2018), and saturation influences the solubility of both $P_{i}$ and $P_{o}$ (Heckrath et al., 1995), ignoring $P_{o}$ sorption and $\mathrm{C}_{\mathrm{o}}$ saturation dynamics may limit the predictive capability of DPS measurements and sorption indices. $\mathrm{P}_{\mathrm{o}}$ and $\mathrm{C}_{\mathrm{o}}$ saturation are generally not determined and are not explicitly simulated in models, despite the potential interactions between $\mathrm{P}_{\mathrm{i}}$ and $\mathrm{P}_{\mathrm{O}}$ in the soil and the role of $\mathrm{P}_{\mathrm{o}}$ in plant fertility.

\subsection{Modeling the effects of $\mathrm{C}_{\mathbf{0}}$ saturation on $\mathbf{P}_{0}$ mineralization}

Similar to $\mathrm{P}, \mathrm{C}_{\mathrm{o}}$ can be stabilized in the soil by sorption to silts and clays (Hassink and Whitmore, 1997) and during aggregate formation (Six et al., 2002). Sorption proceeds with the formation of organo-mineral complexes. The $\mathrm{C}_{\mathrm{o}}$ saturation $\left(\mathrm{C}_{\mathrm{X}}\right)$ can be calculated based on the clay and silt content of the soil (Table 2; Eq. 1; Hassink and Whitmore, 1997). The saturation of $\mathrm{C}_{\mathrm{o}}$ has implications for the storage of $\mathrm{C}$, decomposition, and the mineralization of nutrients (Kemanian and Stöckle, 2010; Kemanian et al., 2011; Castellano et al., 2012; White et al., 2014).

The dynamics of explicit $\mathrm{C}_{\mathrm{o}}$ saturation are only included in a few models (Kemanian and Stöckle, 2010; White et al., 2014; Ahrens et al., 2015), and its effect on $\mathrm{P}_{\mathrm{o}}$ mineralization is unexplored in models. The limited number of studies on $\mathrm{C}_{\mathrm{o}}$ saturation and $\mathrm{N}$ cycling demonstrate that $\mathrm{C}_{\mathrm{o}}$ saturation is positively correlated with $\mathrm{N}$ mineralization (Castellano et al., 2012), likely because $\mathrm{C}_{\mathrm{o}}$ saturation reduces the $\mathrm{C}$ transfer efficiency or rate to stable pools, thus increasing the mineralization of labile $\mathrm{N}$ (White et al., 2014). This relationship is expected to be seen between $\mathrm{P}_{\mathrm{o}}$ mineralization and $\mathrm{C}_{\mathrm{o}}$ saturation (Fig. 7b). The effects of $\mathrm{C}_{\mathrm{o}}$ saturation are most readily seen in soils with high $\mathrm{C}_{\mathrm{o}}$ accumulation (top layer of stratified, undisturbed no-till systems; Mazzilli et al., 2014; Pravia et al., 2019), or soils with a low clay content (Castellano et al., 2012). More studies are needed, especially in areas with an $\mathrm{C}_{\mathrm{o}}$ saturation gradient, to solidify the $\mathrm{C}_{\mathrm{o}}$ saturation concept for $\mathrm{N}$ dynamics (White et al., 2014) and advance it for $\mathrm{P}$, preferably in investigations pairing $\mathrm{N}$ and $\mathrm{P}$.

\subsection{Competitive $\mathrm{C}_{\mathrm{o}}$ anion sorption}

Experiments on $\mathrm{C}_{\mathrm{o}}$ saturation suggest that, as the $\mathrm{C}_{\mathrm{o}}$ content of the soil increases, so does the lability, solubility, and ultimate transport of $\mathrm{P}_{\mathrm{i}}$ from the soil (Reddy et al., 1980; Walbridge et al., 1991; Erich et al., 2002; Guppy et al., 2005; 
$\mathrm{C}_{\mathrm{o}}$ anion- $\mathrm{P}_{\mathrm{i}}$ competitive sorption (a)
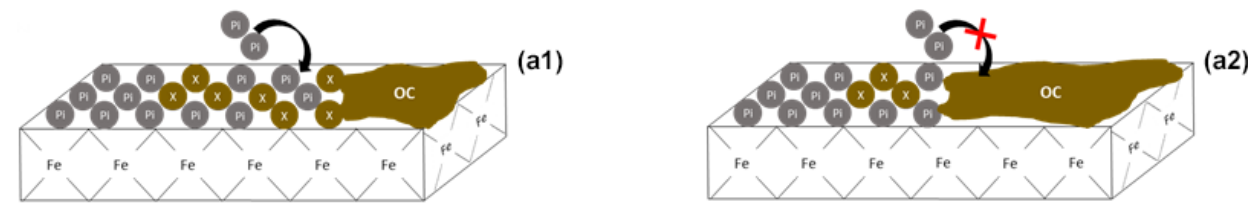

$\mathrm{C}_{\mathrm{o}}$ saturation increases $\mathrm{P}_{\mathrm{o}}$ mineralization $(\mathrm{b})$

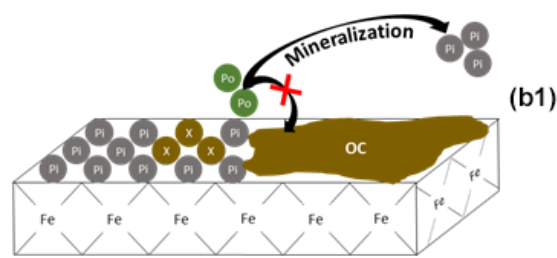

Disparities in DPS (c)

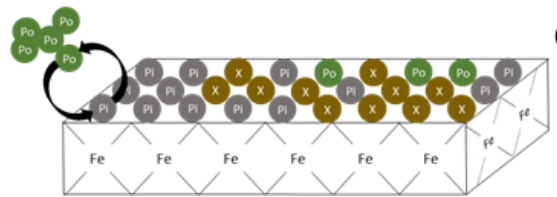

(c1)

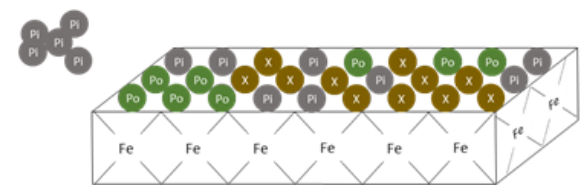

(c2)

Figure 7. Conceptual depiction of $P_{i}$ and $P_{0}$ saturation dynamics. The green $P_{0}$ bubbles are organic phosphate, the gray $P_{i}$ bubbles are inorganic phosphate, and the brown $\mathrm{X}$ bubbles are non-P bearing organic and inorganic compounds. Panels (a1) and (a2) represent the competitive sorption of non-P-bearing organic carbon $\left(\mathrm{C}_{\mathrm{o}}\right)$ compounds on the sorption of $\mathrm{P}_{\mathrm{i}}$. As $\mathrm{C}_{\mathrm{o}}$ saturation increases (a2), so does the solution concentration of $\mathrm{P}_{\mathrm{i}}$. Panel (b1) shows the increase in $\mathrm{C}_{\mathrm{o}}$ from (a2), causing an increase in $\mathrm{P}_{\mathrm{o}}$ mineralization rather than a decrease in $P_{i}$ sorption. Panels (c1) and (c2) depict the replacement of $P_{i}$ with $P_{o}$ on an iron oxide mineral surface, resulting in a change in the composition of the saturated surface. Because DPS measurements do not target $\mathrm{P}_{\mathrm{O}}$, the measured DPS would be lower for mineral (c2), despite having the same overall $\mathrm{P}$ content. The replacement of $\mathrm{P}_{\mathrm{i}}$ with $\mathrm{P}_{\mathrm{O}}$ on sorption surfaces would increase the $\mathrm{C}: \mathrm{P}$ ratio of the soil.

Table 1. Hypothetical scenarios comparing the measured $P_{i}$ saturation (DPS) and actual total P saturation.

\begin{tabular}{|c|c|c|c|c|c|c|c|c|}
\hline Figure & Scenario & $\begin{array}{l}\text { Presence } \\
\text { of } \mathrm{C}_{\mathrm{o}}\end{array}$ & $\begin{array}{r}\text { Total } \mathrm{P}_{\mathrm{i}} \\
\left(\mathrm{mg} \mathrm{Pkg}^{-1}\right)\end{array}$ & $\begin{array}{r}\text { Total } \mathrm{P}_{\mathrm{o}} \\
\left(\mathrm{mg} \mathrm{Pkg}^{-1}\right)\end{array}$ & $\begin{array}{r}\mathrm{P}_{\mathrm{i}} \text { and } \mathrm{P}_{\mathrm{O}} \\
\text { saturation cap. } \\
\left(\mathrm{mg} \mathrm{Pkg}{ }^{-1}\right)\end{array}$ & $\begin{array}{r}\text { Measured } \\
\mathrm{P}_{\mathrm{i}} \text { saturation } \\
(\mathrm{DPS} ; \%)\end{array}$ & $\begin{array}{r}\mathrm{P}_{\mathrm{O}} \text { saturation } \\
(\%)\end{array}$ & $\begin{array}{r}\text { Actual total } \\
\text { P saturation } \\
(\%)\end{array}$ \\
\hline NA & $\begin{array}{l}\mathrm{Fe} / \mathrm{Al} \text { oxide mineral } \\
\left(\mathrm{No}_{\mathrm{i}}, \mathrm{P}_{\mathrm{o}}\right)\end{array}$ & No & 0 & 0 & 500 & 0 & 0 & 0 \\
\hline NA & $\begin{array}{l}\text { Complete } \mathrm{P}_{\mathrm{i}} \text { saturation } \\
\left(\mathrm{No}_{\mathrm{O}}\right)\end{array}$ & No & 500 & 0 & 500 & 100 & 0 & 100 \\
\hline $7 \mathrm{a}$ & $\begin{array}{l}\text { Incomplete } \mathrm{P}_{\mathrm{i}} \text { saturation } \\
\text { (No } \mathrm{P}_{\mathrm{o}} ; \mathrm{C}_{\mathrm{o}} \text { competing with } \mathrm{P}_{\mathrm{i}} \\
\text { for sorption) }\end{array}$ & Yes & 400 & 0 & 500 & 80 & 0 & 100 \\
\hline $7 \mathrm{c}$ & $\begin{array}{l}\text { Incomplete } \mathrm{P}_{\mathrm{i}} \text { saturation } \\
\left(\mathrm{P}_{\mathrm{o}} \text { competing with } \mathrm{P}_{\mathrm{i}}\right. \\
\text { for sorption })\end{array}$ & No & 300 & 200 & 500 & 60 & 40 & 100 \\
\hline
\end{tabular}

Actual $P$ saturation is defined as the total saturation of both $P_{0}$ and $P_{i}$ species. The competition with non-P-bearing $C_{o}$ anions (Fig. 7a) would lower the measured DPS despite the saturation of all available sorption sites. When $P_{0}$ successfully competes with $P_{i}$ for sorption (Fig. 7c), the resulting measured DPS will be lower than the actual P saturation. It is important to note that, as opposed to colorimetric methods, if inductively coupled plasma optical emission spectrometry (ICP-OES) is used in DPS analysis, any circumstantially extracted $\mathrm{P}_{\mathrm{o}}$ would be included in the measurement, resulting in a higher \% DPS than presented here. Note: NA - not available. 
Table 2. Equations for modeling sorption dynamics.

\begin{tabular}{|c|c|c|c|}
\hline \# & Name & Equation & Parameters \\
\hline 1 & $\begin{array}{l}\text { C sorption } \\
\text { capacity }\end{array}$ & $\mathrm{C}_{\mathrm{X}}=21.1+37.5 \cdot f_{\text {clay }}$ & $\begin{array}{l}\mathrm{C}_{\mathrm{X}}-\text { maximum sorption } \mathrm{C} \text { capacity }\left(\mathrm{g} \mathrm{C} \mathrm{kg}^{-1}\right) \text { soil } \\
f_{\text {clay }} \text { - clay concentration }\left(\mathrm{g} \mathrm{kg}^{-1}\right)\end{array}$ \\
\hline 2 & Langmuir & $\frac{C}{S}=\frac{C}{S_{\max }}+\frac{1}{K_{\mathrm{L}} \cdot S_{\max }}$ & $\begin{array}{l}S-\text { sorbed } \mathrm{P}\left(\mathrm{mg} \mathrm{kg}^{-1}\right) \\
C-\text { equilibrium } \mathrm{P} \text { concentration }\left(\mathrm{mg} \mathrm{L}^{-1}\right) \\
S_{\max }-\text { sorption maximum }\left(\mathrm{mg} \mathrm{kg}^{-1}\right) \\
K_{\mathrm{L}}-\text { binding energy constant }\end{array}$ \\
\hline 3 & Freundlich & $S=a \cdot c^{b}$ & $\begin{array}{l}S-\text { sorbed } \mathrm{P}\left(\mathrm{mg} \mathrm{kg}^{-1}\right) \\
\mathrm{a}-\text { proportionality constant }\left(\mathrm{mg} \mathrm{kg}^{-1} / \mathrm{mg} \mathrm{L}^{-1}\right) \\
b-\text { empirical binding energy coefficient }(\text { dimensionless }) \\
c-\mathrm{P} \text { concentration in solution }\left(\mathrm{mgL}^{-1}\right)\end{array}$ \\
\hline 4 & $\begin{array}{l}\text { Two-surface } \\
\text { Langmuir }\end{array}$ & $\frac{x}{m}=\frac{b_{\mathrm{I}} K_{\mathrm{I}} E P C}{1+K_{\mathrm{I}} E P C}+\frac{b_{\mathrm{II}} K_{\mathrm{II}} E P C}{1+K_{\mathrm{II}} E P C}$ & $\begin{array}{l}x / m-\text { sorbed } \mathrm{P}\left(\mathrm{mg} \mathrm{kg}^{-1}\right) \\
K_{\mathrm{I}} / K_{\mathrm{II}}-\text { bonding energy; regions I and II }\left(\mathrm{L} \mathrm{mg}^{-1}\right) \\
b_{\mathrm{I}} / b_{\mathrm{II}}-\text { adsorption maximum; regions I and II }\left(\mathrm{mg} \mathrm{kg}^{-1} \text { soil }\right) \\
\text { EPC - equilibrium } \mathrm{P} \text { concentration }\left(\mathrm{mgL} \mathrm{L}^{-1}\right)\end{array}$ \\
\hline 5 & $\begin{array}{l}\text { PSP - calcareous } \\
\text { soils }\end{array}$ & $\mathrm{PSP}=0.58-0.0061 \cdot \mathrm{CaCO}_{3}$ & $\begin{array}{l}\mathrm{PSP}-\mathrm{P} \text { sorption parameter* } \\
\mathrm{CaCO}_{3}-\text { calcium carbonate }(\%)\end{array}$ \\
\hline 6 & $\begin{array}{l}\text { PSP - slightly } \\
\text { weathered soils }\end{array}$ & $\begin{array}{l}\mathrm{PSP}=-0.70-0.0043 \cdot \mathrm{BS} \\
+0.0034 \cdot \mathrm{P}_{\mathrm{il}}+0.11 \cdot \mathrm{pH}\end{array}$ & $\begin{array}{l}\mathrm{BS} \text { - base saturation }(\%) \\
\mathrm{P}_{\mathrm{il}}-\text { labile } \mathrm{P}\left(\mu \mathrm{gg}^{-1} \text { soil }\right) \\
\mathrm{pH}\end{array}$ \\
\hline 7 & $\begin{array}{l}\text { PSP - highly } \\
\text { weathered soils }\end{array}$ & $\begin{array}{l}\mathrm{PSP}=0.038-0.047 \cdot \ln \left(\frac{f_{\text {clay }}}{10}\right) \\
+0.045 \cdot \mathrm{P}_{\mathrm{il}}-0.053 \cdot \mathrm{OC}\end{array}$ & $\begin{array}{l}f_{\text {clay }} \text { - clay concentration }\left(\mathrm{g} \mathrm{kg}^{-1}\right) \\
\mathrm{OC}-\text { organic carbon }(\%)\end{array}$ \\
\hline
\end{tabular}

Equations mentioned that take different approaches to describing P and C sorption dynamics. Equation (1) - Hassink and Whitmore (1997). Equations (2) and (3) Barrow (2008) and Dari et al. (2015). Equation (4) - Zhang et al. (2005). Equations (5)-(7) - Sharpley et al. (1984) and Vadas et al. (2010). * Also known as the phosphorus availability index (PAI).

Abdala et al., 2012; Gao et al., 2014). On a molecular basis, this can be attributed to the competitive saturation of sorption sties by $\mathrm{C}_{\mathrm{o}}$ anions, as reported in other studies (Ohno and Crannell, 1996; Staunton and Leprince, 1996; Antelo et al., 2007; Hunt et al., 2007; Fig. 7a). Guppy et al. (2005) claim that the observed decrease in $\mathrm{P}_{\mathrm{i}}$ sorption is not attributable to competition for sorption sites but, instead, to the increased mineralization of P-bearing $\mathrm{C}_{\mathrm{o}}$ compounds, akin to the White et al. (2014) model (Fig. 7b). These mechanisms are not necessarily mutually exclusive. For example, as soils move closer to $\mathrm{C}$ saturation, $\mathrm{N}$ mineralization increases because the soils lack new sites for $\mathrm{C}_{\mathrm{o}}$ to be stabilized on minerals (Castellano et al., 2012; White et al., 2014). Regardless of the proposed mechanisms, in order to improve $\mathrm{P}$ modeling, accounting for competitive sorption reactions (Regelink et al., 2015) or the increase in $P_{i}$ content from mineralization or $P_{i}$ release (Guppy et al., 2005) is a necessity.

\subsection{The contribution of $P_{0}$ to DPS and the interactions between $P_{i}$ and $P_{0}$}

A common method for characterizing sorption dynamics is to develop a soil sorption isotherm, or sorption curve, which requires equilibrating various concentrations of $P_{i}$ with a soil sample. Although, to a lesser extent, $\mathrm{P}_{\mathrm{o}}$ sorption dynamics have also been studied using sorption isotherms. Instead of using $P_{i}$ in the equilibrating solution, different forms of $P_{o}$ can be added together or separately with $\mathrm{P}_{\mathrm{i}}$ and their sorption dynamics can be compared (Anderson et al., 1974; McKercher and Anderson, 1989; Berg and Joern, 2006). The $\mathrm{PO}_{4}$ ion on $\mathrm{P}_{\mathrm{o}}$ partially controls its sorption, so $\mathrm{P}_{\mathrm{o}}$ compounds share similar sorption dynamics with $\mathrm{P}_{\mathrm{i}} . \mathrm{P}_{\mathrm{o}}$ 's affinity to the soil phase increases with the number of phosphate groups (Shang et al., 1990). Due to the steric hindrance of the C moiety (Celi et al., 1999) it is suspected that $P_{0}$ does not readily penetrate mineral pores (Shang et al., 1992). However, the similar surface binding mechanisms of $P_{o}$ and $P_{i}$ likely means they compete for surface sorption sites, which has implications for the solubility of both $\mathrm{P}_{\mathrm{o}}$ and $\mathrm{P}_{\mathrm{i}}$ and, thus, its availability for plant uptake or hydrologic losses.

When multiple $P_{o}$ species and $P_{i}$ are added to the equilibration solution of a sorption isotherm experiment, the affinity of each species can be measured in competition with one another. $\mathrm{P}_{\mathrm{o}}$ generally exhibits less efficient sorption than $\mathrm{P}_{\mathrm{i}}$, except for phytate. Phytate sorption dynamics are debated, with some reports stating that phytate sorbs to a greater extent than $\mathrm{P}_{\mathrm{i}}$ (McKercher and Anderson, 1989; Berg and Jo- 
ern, 2006; Wang et al., 2007) and others showing the opposite result (Shang et al., 1990; Ognalaga et al., 1994; Lilienfein et al., 2004).

An explanation parsimonious with both results is that $\mathrm{P}_{\mathrm{o}}$ with multiple phosphate groups may sorb more strongly, while $\mathrm{P}_{\mathrm{i}}$ may sorb more rapidly. The $\mathrm{P}_{\mathrm{o}}$ sorption strength increases with the number of phosphate groups (Shang et al., 1990; Berg and Joern, 2006). When compounds like phytate are present in a soil, stabilized by mineral interactions, and not readily mineralized, $\mathrm{P}_{\mathrm{i}}$ saturation should decrease due to the lower net desorption of $\mathrm{P}_{\mathrm{o}}$ (Table 1; Fig. 7c). In contrast, cases showing preferential sorption of $\mathrm{P}_{i}$ over $\mathrm{P}_{\mathrm{o}}$ might be explained by the lower activation energy needed for a $\mathrm{PO}_{4}$ ion to bind to soil, compared to a more complex mono or diester organic compound. Both processes are likely co-occurring; $\mathrm{P}_{\mathrm{o}}$ may sorb stronger, particularly if it has more $\mathrm{PO}_{4}$ groups, but $\mathrm{P}_{\mathrm{i}}$ may sorb faster due to its low activation energy and lower steric hindrance (Shang et al., 1990). Yet, we lack an understanding of the conditions that cause one of these processes to dominate in a soil environment.

The accumulation of $\mathrm{P}_{0}$ has implications for how DPS measurements of $P_{i}$ are in interpreted; $P_{0}$ can competitively sorb with $P_{i}$ and reduce the measured, but not actual, DPS. $P_{o}$ saturation may influence $P_{o}$ mineralization dynamics and should be the subject of future empirical and modeling work. This can be critical for understanding $\mathrm{P}$ pollution from soils with high organic $\mathrm{C}$ and high $\mathrm{P}_{\mathrm{o}}$, a condition that is becoming more prevalent with the advancement of no-till in manured soils or in any soil receiving an ample supply of manure.

\subsection{Synthesis}

Advances in understanding $\mathrm{P}_{\mathrm{o}}$ dynamics and its relation to $\mathrm{P}_{\mathrm{i}}$ and $\mathrm{C}_{\mathrm{o}}$ saturation are required in three areas. First, the contributing role of $\mathrm{P}_{\mathrm{o}}$ to $\mathrm{P}$ saturation and, thus, to greater $\mathrm{P}$ sorption and cycling dynamics must be further investigated. This includes determining the effect of $\mathrm{P}_{\mathrm{o}}$ on DPS measurements, for $\mathrm{P}_{\mathrm{o}}$ is implicitly considered in the denominator but not always in the numerator of the DPS calculation. Second, the controls on P sorption of litter application, rhizosphere exudation and deposition, or native $C_{o}$ needs to be clarified. Organic additions can increase $P_{i}$ in the solution due to $P_{o}$ mineralization (as proposed by Guppy et al., 2005) or by increasing the solubility of $\mathrm{P}_{\mathrm{i}}$ (as proposed by Hunt et al., 2007; Oburger et al., 2011; Regelink et al., 2015). Both processes may be co-occurring, but it is critical to define the conditions under which one or the other dominates. And, third, modeling and experimental efforts are needed to determine the effect of $\mathrm{C}$ saturation on $\mathrm{P}_{\mathrm{O}}$ mineralization, as has been done for N (White et al., 2014). These efforts may need to consider phytate and nonphytate compounds as two separate pools. In soils that are amended with manure, $\mathrm{C}$ saturation and $\mathrm{P}$ saturation can be critical controls of both $\mathrm{C}$ and $\mathrm{P}$ turnover.

\section{Methodological discrepancies between $P$ analyses and implied $P$ dynamics}

\subsection{Soil $P_{i}$ and $P_{o}$ pools}

Soil $\mathrm{P}_{\mathrm{i}}$ and $\mathrm{P}_{\mathrm{o}}$ forms vary in turnover rates along a continuum of stabilization (Tiessen and Moir, 1993). To model their dynamics, $P_{i}$ and $P_{o}$ are subdivided into pools, with the exception of Ecosys that simulates $P_{i}$ dynamics using dozens of element and mineral-specific equilibrium reactions (Grant and Heaney, 1997). In most models, these pools are conceptual and are not representable as analytical fractions (Gijsman et al., 1996; Six et al., 2002) such as those determined by the Hedley fractionation method. This is in part because analytical fractions do not always respond, in a quantifiable manner, directly to inputs and outputs (Delve et al., 2009). Despite this limitation, conceptual pools are still estimated by establishing relationships between $P$ stability and changes in pool sizes or transformations using isotope tracing (Hedley et al., 1982; Stewart and Tiessen, 1987; Taranto et al., 2000; Helfenstein et al., 2020).

Among the consequences of the lack of correspondence between modeled and measured pools are that these models may need calibration, and that as $P_{i}$ and $P_{o}$ decrease or increase, there is no assurance that the calibrated parameter values will remain valid outside the calibration domain. $\mathrm{P}$ is distributed into pools based on its stability and cycling rate, and the more stable pools are thought to be available over decadal timescales (Richter et al., 2006) through the slow replenishment of labile fractions (Guo et al., 2000). However, both inorganic and organic $\mathrm{P}$ forms are likely accessible on shorter, seasonal timescales. For example, phytate, which is often considered highly stable, has been observed to mineralize rapidly (Doolette et al., 2010). For $\mathrm{P}_{\mathrm{i}}$, extracted pools that are considered stable, such as the $\mathrm{HCl}$ fraction, have a greater short-term turnover than previously thought (Joshi et al., 2016; Siebers et al., 2018), so models with invariable cycling rates will not be able to represent this dynamic.

\subsection{Sorption curves}

Inherently linked to the stabilization of phosphate in various soil phases are the processes and rates of phosphate sorption. Sorption curves, often referred to as sorption isotherms, are used to determine the extent of rapid P sorption between the solution P and the soil (McGechan and Lewis, 2002). Three problems arise from the use of sorption curves, namely they are soil-dependent rather than generalizable, the methods involved in generating the curve can influence the sorption isotherm parameterization and the modeled $\mathrm{P}$ dynamics, and the P sorption-desorption pathways are hysteretic (Barrow, 1983, 2008; Okajima et al., 1983; Grant and Heaney, 1997).

Because sorption isotherms are time consuming and are not part of routine soil analyses, $\mathrm{P}$ is often modeled using sorption curve parameters that do not always represent the 
simulated soil. The general applicability of sorption curves is further reduced because they are not mechanistic and do not account for site-specific differences in $\mathrm{pH}$, ionic strength, or surface complexation (Grant and Heaney 1997; Arai and Sparks, 2007).

Typically, the generation of sorption curves involves shaking P solutions with a range of known concentrations with a soil sample. After 16-24h, the equilibrium P concentration is measured and the curve is fitted. If the shaking is too vigorous, new sorption sites can be exposed, and the isotherm is no longer representative of $\mathrm{P}$ sorption (Barrow, 2008). Furthermore, parameterizing the hysteretic nature of $\mathrm{P}$ involves time-consuming methodologies (Limousin et al., 2007), but its exclusion results in model uncertainty.

Fitting curves generated by isotherm experiments can also be problematic. The equations by Langmuir (Table 2; Eq. 2) and Freundlich (Table 2; Eq. 3) are commonly used to fit sorption curves. The Langmuir isotherm assumes a reaction with a uniform sorption surface, which does not occur in soils. Freundlich isotherms assume an infinite number of sorption sites (Kruse et al., 2015), i.e., no sorption maximum is considered as it is in the Langmuir. Neither the general Langmuir nor Freundlich equations account for multiple possible sorption pathways, which may result in their underestimation of sorption (Hussain et al., 2012) and reduced fit (McGechan and Lewis, 2002). Two-phase Langmuir equations (Table 2; Eq. 4) can be used as they have provided a better fit for sorption isotherms in some cases (Holford et al., 1974; Hussain et al., 2012). However, using the same soils as Holford et al. (1974), Barrow (1978) demonstrated that the Freundlich had comparable fits with reduced parameters, which may explain the absence of two-phase Langmuirs in simulation models.

Sharpley et al. (1984) employed a longer and more intensive approach to estimating a $\mathrm{P}$ sorption parameter (PSP), which is the percentage of added $\mathrm{P}$ remaining in the soil solution after equilibrium is reached with a labile active pool (Vadas et al., 2013). In lieu of a $24 \mathrm{~h}$ incubation, known $\mathrm{P}$ concentrations were added to subsamples that were dried and rewetted three times with deionized (DI) water over a period of 6 months. Three general equations were developed for calcareous, slightly weathered, and highly weathered soils. These equations were integrated into the Soil and Water Assessment Tool (SWAT) model (Arnold et al., 1998), which is built on the CREAMS, GLEAMS, and EPIC model structures (Knisel, 1980; Jones et al., 1984; Leonard et al., 1987). Although this model accounts for temperature and moisture factors, $\mathrm{pH}$ is grouped into large categories, which may limit its applicability to the highly variable nature of soils. Furthermore, Eq. (7) shows that $C_{o}$ has a negative relationship with PSP, which is the opposite of the expected response as outlined in Sect. 4.2 which deals with competitive $\mathrm{C}_{\mathrm{o}}$ anion sorption. In SWAT, this PSP variable and the solution P are used to calculate the size of pools in the model. However, solution $\mathrm{P}$ is assumed to be half of Mehlich 3 or other soil test phosphorus (STP) methods. This may work for initialization before model spin up, or at least provide a consistent method, but it is not a representative method in determining $P$ pool sizes.

An alternative to both isotherm methods is the use of known equilibrium constants of various soil minerals and precipitates to calculate an equilibrium of sorbed or mineral P with the soil. Such an approach was taken by Grant and Heaney (1997) in the Ecosys model. Although based on first principles, it relies on obtaining concentrations of many soil minerals, which may be impractical or difficult. For reliable parameterization, it would also require knowing the effective mineral-solution contact; larger minerals or colloids would have a lower surface area for $\mathrm{P}$ exchange compared to smaller colloids.

\subsection{Synthesis}

Translating analytical P pools into models is complicated by the fact that extracted pools are not compound specific and only provide an estimation of $\mathrm{P}_{\mathrm{i}}$ and $\mathrm{P}_{\mathrm{o}}$ turnover rates. This issue is exacerbated by the diversity among and within chemical extraction protocols. The most used extraction method, the Hedley fractionation method, is also the most heavily modified, with dozens of variations. This is a weak foundation for the comparison and meta-analysis of data from studies employing variations of the Hedley protocol. If we are to incorporate measurable pools into models, these pools need to be measured with a consistent protocol, and efforts towards measuring $\mathrm{P}$ turnover and transformations using $\mathrm{P}$ radioisotope (Helfenstein et al., 2020) and oxygen isotope tracing (Joshi et al., 2016) must be continued. Although efforts in this space have been made (Joshi et al., 2018), it is necessary to continue coupling ${ }^{31} \mathrm{P}$ spectroscopy and chemical extractions to determine pool compositions and tracing to assess compound-specific lability.

Conducting sorption isotherms is tedious and is not part of standard soil tests. Applying isotherm parameters, such as the binding energy constant $\left(K_{\mathrm{L}}\right)$ when predicting or generating data can result in poor validation, as the conditions from which the parameter was derived likely do not match the simulated conditions. If an isotherm approach is to be used, then it will be necessary to employ methods to rapidly estimate the sorption parameters from accessible and costeffective techniques, such as in Dari et al. (2015). In future method development, factors that influence sorption, such as the $\mathrm{C}_{\mathrm{o}}$ content of the soil, should be considered. This is of particular importance as $\mathrm{P}$ isotherms are sometimes used to determine the saturation capacity, a necessary component of DPS measurements. As previously discussed in Sect. 4, organic $\mathrm{P}$ and $\mathrm{C}$ saturation, the presence of $\mathrm{P}_{\mathrm{o}}$ and $\mathrm{C}_{\mathrm{o}}$ may influence the interpretation of DPS data.

Improved accessibility of mineral analysis methods will facilitate the application of a bottom-up, first-principles approach such as the dynamic equilibrium approach of Ecosys 
(Grant and Heaney, 1997). If the approach of Sharpley et al. (1984) is to be revised and expanded, soil-specific properties $\left(\mathrm{C}_{\mathrm{o}}, \mathrm{pH}\right.$, clay content, etc.) must be accounted for in a continuum that can be generalized. Furthermore, pool-pool transfer functions could benefit from the application of isotope tracing techniques; this is an area which clearly requires more fundamental research.

\section{Conclusions}

Limitations in simulating $\mathrm{P}_{\mathrm{i}}$ sorption, $\mathrm{P}_{\mathrm{o}}$ mineralization, stoichiometry as it relates to $\mathrm{P}$, and nutrient interactions call for an improved experimental and modeling framework to interpret $\mathrm{P}$ cycling. Our current knowledge of soil P dynamics suffices for the management of crop nutrition but still lags $\mathrm{C}$ and $\mathrm{N}$ in terms of process-based modeling (Beegle, 2005). We recommend focusing specifically on (1) updating the McGill and Cole model, (2) understanding the dynamics of phytate and soil stoichiometry, (3) exploring the role of $\mathrm{C}_{\mathrm{o}}$ and $\mathrm{P}_{\mathrm{o}}$ saturation on $\mathrm{P}$ sorption and $\mathrm{P}_{\mathrm{o}}$ mineralization, and (4) resolving discrepancies between hypotheses about $P$ cycling and methods for measuring $\mathrm{P}$ pools and fluxes.

It is necessary to better understand $\mathrm{P}$ processes to build the most representative simulation models. Understanding the controls on plant, microbial biomass, and microbial stoichiometry will help determine bottom-up controls on ecosystem, biome, and even global $\mathrm{P}$ cycling. The challenges summarized in this review will hopefully steer research efforts towards a better empirical understanding of the $\mathrm{P}$ cycle that will ultimately reduce the reliance on intensive calibration (Beven et al., 2006). A better understanding of $\mathrm{P}$ cycling will lay the stratum upon which better predictive models will be developed, enabling foresight of both plant $\mathrm{P}$ nutrition and $\mathrm{P}$ pollution challenges rather than reacting to them when symptoms like surface water eutrophication manifest visibly and in full force.

Data availability. Any data presented in this paper were referenced appropriately throughout the paper.

Author contributions. ARK, CAM, and JPK conceived the paper. CAM conducted the literature search and organized and summarized information. CAM, ARK, and JPK defined the organizational structure after the literature search, and CAM drafted the paper and prepared the figures. ARK and JPK contributed to the discussion and edited the paper. ARK and JPK secured the funding to support this research.
Competing interests. The authors declare that they have no conflict of interest.

Financial support. Funding for this research was provided by the USDA National Institute of Food and Agriculture (grant no. 201667003-24966), under Hatch Appropriations (grant no. PEN04571) and accession (grant no. 003346), and the US Department of Energy award (grant no. EE0007088).

Review statement. This paper was edited by Sönke Zaehle and reviewed by Clive Kirkby and Lin Yu.

\section{References}

Abdala, D. B., Ghosh, A. K., da Silva, I. R., de Novais, R. F., and Alvarez Venegas, V. H.: Phosphorus saturation of a tropical soil and related $\mathrm{P}$ leaching caused by poultry litter addition, Agr. Ecosyst. Environ., 162, 15-23, https://doi.org/10.1016/j.agee.2012.08.004, 2012.

Achat, D. L., Augusto, L., Gallet-Budynek, A., and Loustau, D.: Future challenges in coupled $\mathrm{C}-\mathrm{N}-\mathrm{P}$ cycle models for terrestrial ecosystems under global change: a review, Biogeochemistry, 131, 173-202, https://doi.org/10.1007/s10533-016-0274-9, 2016.

Adams, M. A. and Pate, J. S.: Availability of organic and inorganic forms of phosphorus to lupins (Lupinus spp.), Plant Soil, 145, 107-113, https://doi.org/10.1007/BF00009546, 1992.

Ahrens, B., Braakhekke, M. C., Guggenberger, G., Schrumpf, M., and Reichstein, M.: Contribution of sorption, DOC transport and microbial interactions to the ${ }^{14} \mathrm{C}$ age of a soil organic carbon profile: Insights from a calibrated process model, Soil Biol. Biochem., 88, 390-402, https://doi.org/10.1016/j.soilbio.2015.06.008, 2015.

Allison, S. D.: A trait-based approach for modelling microbial litter decomposition, Ecol. Lett., 15, 1058-1070, https://doi.org/10.1111/j.1461-0248.2012.01807.x, 2012.

Allison, S. D. and Vitousek, P. M.: Responses of extracellular enzymes to simple and complex nutrient inputs, Soil Biol. Biochem., 37, 937-944, https://doi.org/10.1016/j.soilbio.2004.09.014, 2005.

Anderson, G., Williams, E. G., and Moir, J. O.: A Comparison of the Sorption of Inorganic Orthophosphate and Inositol Hexaphosphate by Six Acid Soils, J. Soil Sci., 25, 51-62, https://doi.org/10.1111/j.1365-2389.1974.tb01102.x, 1974.

Angert, A., Weiner, T., Mazeh, S., Tamburini, F., Frossard, E., Bernasconi, S. M., and Sternberg, M.: Seasonal variability of soil phosphate stable oxygen isotopes in rainfall manipulation experiments, Geochim. Cosmochim. Ac., 75, 4216-4227, https://doi.org/10.1016/j.gca.2011.05.002, 2011.

Antelo, J., Arce, F., Avena, M., Fiol, S., López, R., and Macías, F.: Adsorption of a soil humic acid at the surface of goethite and its competitive interaction with phosphate, Geoderma, 138, 12-19, https://doi.org/10.1016/j.geoderma.2006.10.011, 2007.

Aponte, C., Marañón, T., and García, L. V.: Microbial C, N and $\mathrm{P}$ in soils of Mediterranean oak forests: Influence of season, 
canopy cover and soil depth, Biogeochemistry, 101, 77-92, https://doi.org/10.1007/s10533-010-9418-5, 2010.

Arai, Y. and Sparks, D. L.: Phosphate Reaction Dynamics in Soils and Soil Components: A Multiscale Approach, Adv. Agron., 94, 135-179, https://doi.org/10.1016/S0065-2113(06)94003-6, 2007.

Arenberg, M. R. and Arai, Y.: Uncertainties in soil physicochemical factors controlling phosphorus mineralization and immobilization processes, in: Advances in Agronomy, Vol. 154, Elsevier, Cambridge, MA, 153-200, 2019.

Arnold, J. G., Srinivasan, R., Muttiah, R. S., and Williams, J. R.: Large Area Hydrologic Modeling and Assessment Part I: Model Development, J. Am. Water Resour. As., 34, 73-89, https://doi.org/10.1111/j.1752-1688.1998.tb05961.x, 1998.

Asmar, F.: Variation in activity of root extracellular phytase between genotypes of barley, Plant Soil, 195, 61-64, https://doi.org/10.1023/A:1004291512285, 1997.

Asmar, F., Singh, T., Gahoonia and Nielsen, N. E.: Barley genotypes differ in activity of soluble extracellular phosphatase and depletion of organic phosphorus in the rhizosphere soil, Plant Soil, 172, 117-122, https://doi.org/10.1007/BF00020865, 1995.

Barrow, N. J.: The Description of Phosphate Adsorption Curves, J. Soil Sci., 29, 447-462, https://doi.org/10.1111/j.13652389.1978.tb00794.x, 1978.

Barrow, N. J.: On the reversibility of phosphate sorption by soils, J. Soil Sci., 34, 751-758, https://doi.org/10.1111/j.13652389.1983.tb01069.x, 1983.

Barrow, N. J.: The description of sorption curves, Eur. J. Soil Sci., 59, 900-910, https://doi.org/10.1111/j.1365-2389.2008.01041.x, 2008.

Beegle, D.: Assessing soil phosphorus for crop production by soil testing, in: Phosphorus: Agriculture and the environment, edited by: Sims, J. T. and Sharpley, A. N., ASA, CSSA, and SSSA, Madison, WI, 123-143, 2005.

Belinque, H., Pucheu, N., Kerber, N., and Rubio, G.: Utilization of organic phosphorus sources by oilseed rape, sunflower, and soybean, J. Plant Nutr. Soil Sc., 178, 339-344, https://doi.org/10.1002/jpln.201400301, 2015.

Berg, A. S. and Joern, B. C.: Sorption Dynamics of Organic and Inorganic Phosphorus Compounds in Soil, J. Environ. Qual., 35, 1855-1862, https://doi.org/10.2134/jeq2005.0420, 2006.

Beven, K., Page, T., and McGechan, M.: Uncertainty Estimation in Phosphorus Models, in: Modeling Phosphorus in the Environment, edited by: Radcliffe, D. E. and Cabrera, M. L., CRC Press, Boca Raton, FL, 131-160, 2006.

Blake, R. E., O’Neil, J. R., and Surkov, A. V.: Biogeochemical cycling of phosphorus: Insights from oxygen isotope effects of phosphoenzymes, Am. J. Sci., 305, 596-620, https://doi.org/10.2475/ajs.305.6-8.596, 2005.

Breeuwsma, A., Reijerink, J. G. A.. and Schoumans, O. F.: Impact of manure on accumulation and leaching of phosphate in areas of intensive livestock farming, in Animal Waste and the Landwater Interface, edited by: K. F. Steele, 239-249, Lewis Publishers, Boca Raton, 1995.

Bünemann, E. K.: Assessment of gross and net mineralization rates of soil organic phosphorus - A review, Soil Biol. Biochem., 89, 82-98, https://doi.org/10.1016/j.soilbio.2015.06.026, 2015.

Bünemann, E. K., Augstburger, S., and Frossard, E.: Dominance of either physicochemical or biological phospho- rus cycling processes in temperate forest soils of contrasting phosphate availability, Soil Biol. Biochem., 101, 85-95, https://doi.org/10.1016/j.soilbio.2016.07.005, 2016.

Butler, J. S. and Coale, F. J.: Phosphorus Leaching in ManureAmended Atlantic Coastal Plain Soils, J. Environ. Qual., 34, 370-381, https://doi.org/10.2134/jeq2005.0370, 2005.

Camenzind, T., Hättenschwiler, S., Treseder, K. K., Lehmann, A., and Rillig, M. C.: Nutrient limitation of soil microbial processes in tropical forests, Ecol. Monogr., 88, 4-21, https://doi.org/10.1002/ecm.1279, 2018.

Campbell, M., Dunn, R., Ditterline, R., Pickett, S., and Raboy, V.: Phytic acid represents 10 to $15 \%$ of total phosphorus in alfalfa root and crown, J. Plant Nutr., 14, 925-937, https://doi.org/10.1080/01904169109364253, 1991.

Čapek, P., Kotas, P., Manzoni, S., and Šantrůčková, H.: Drivers of phosphorus limitation across soil microbial communities, Funct. Ecol., 30, 1705-1713, https://doi.org/10.1111/1365-2435.12650, 2016.

Čapek, P., Manzoni, S., Kaštovská, E., Wild, B., Diáková, K., Bárta, J., Schnecker, J., Biasi, C., Martikainen, P. J., Alves, R. J. E., Guggenberger, G., Gentsch, N., Hugelius, G., Palmtag, J., Mikutta, R., Shibistova, O., Urich, T., Schleper, C., Richter, A., and Šantrůčková, H.: A plant-microbe interaction framework explaining nutrient effects on primary production, Nature Ecology \& Evolution, 2, 1588-1596, https://doi.org/10.1038/s41559-018 0662-8, 2018.

Castellano, M. J., Kaye, J. P., Lin, H., and Schmidt, J. P.: Linking Carbon Saturation Concepts to Nitrogen Saturation and Retention, Ecosystems, 15, 175-187, https://doi.org/10.1007/s10021011-9501-3, 2012.

Celi, L., Lamacchia, S., Marsan, F. A., and Barberis, E.: Interaction of inositol hexaphosphate on clays: Adsorption and charging phenomena, Soil Sci., 164, 574-585, https://doi.org/10.1097/00010694-199908000-00005, 1999.

Chen, C. R., Condron, L. M., Davis, M. R., and Sherlock, R. R.: Effects of afforestation on phosphorus dynamics and biological properties in a New Zealand grassland soil, Plant Soil, 220, 151163, https://doi.org/10.1023/A:1004712401721, 2000.

Chen, C. R., Condron, L. M., Davis, M. R., and Sherlock, R. R.: Phosphorus dynamics in the rhizosphere of perennial ryegrass (Lolium perenne L.) and radiata pine (Pinus Radiata D. Don.), Soil Biol. Biochem., 34, 487-499, https://doi.org/10.1016/S0038-0717(01)00207-3, 2002.

Clarholm, M.: Microbial biomass P, labile P, and acid phosphatase activity in the humus layer of a spruce forest, after repeated additions of fertilizers, Biol. Fert. Soils, 16, 287-292, https://doi.org/10.1007/BF00369306, 1993.

Cleveland, C. C. and Liptzin, D.: C : N : P stoichiometry in soil: Is there a "Redfield ratio" for the microbial biomass?, Biogeochemistry, 85, 235-252, https://doi.org/10.1007/s10533-007-9132-0, 2007.

Cleveland, C. C., Townsend, A. R., Constance, B. C., Ley, R. E., and Schmidt, S. K.: Soil Microbial Dynamics in Costa Rica: Seasonal and Biogeochemical Constraints, Biotropica, 36, 184-195, https://doi.org/10.1646/03115-Q1562, 2004.

Cleveland, C. C., Houlton, B. Z., Smith, W. K., Marklein, A. R., Reed, S. C., Parton, W., Del Grosso, S. J., and Running, S. W.: Patterns of new versus recycled primary production in the ter- 
restrial biosphere, P. Natl. Acad. Sci. USA, 110, 12733-12737, https://doi.org/10.1073/pnas.1302768110, 2013.

Colvan, S. R., Syers, J. K., and O'Donnell, A. G.: Effect of longterm fertiliser use on acid and alkaline phosphomonoesterase and phosphodiesterase activities in managed grassland, Biol. Fertil. Soils, 34, 258-263, https://doi.org/10.1007/s003740100411, 2001.

Condron, L. M., Turner, B. L., and Cade-Menun, B. J.: Chemistry and dynamics of soil organic phosphorus, in: Phosphorus: Agriculture and the Environment, edited by: Sims, J. T. and Sharpley, A. N., ASA, CSSA, and SSSA, Madison, WI, 87-121, 2005.

Cotner, J. B., Hall, E. K., Scott, J. T., and Heldal, M.: Freshwater bacteria are stoichiometrically flexible with a nutrient composition similar to seston, Front. Microbiol., 1, 132, https://doi.org/10.3389/fmicb.2010.00132, 2010.

Cross, A. F. and Schlesinger, W. H.: A literature review and evaluation of the Hedley fractionation: Applications to the biogeochemical cycle of soil phosphorus in natural ecosystems, Geoderma, 64, 197-214, https://doi.org/10.1016/00167061(94)00023-4, 1995.

Dalal, R. C.: Mineralization of Carbon and Phosphorus from Carbon-14 and Phosphorus-32 Labelled Plant Material Added to Soil1, Soil Sci. Soc. Am. J., 43, 913-916, https://doi.org/10.2136/sssaj1979.03615995004300050019x, 1979.

Dari, B., Nair, V. D., Colee, J., Harris, W. G., and Mylavarapu, R.: Estimation of phosphorus isotherm parameters: a simple and cost-effective procedure, Front. Environ. Sci., 3, 1-9, https://doi.org/10.3389/fenvs.2015.00070, 2015.

Davies, J. A. C., Tipping, E., Rowe, E. C., Boyle, J. F., Graf Pannatier, E., and Martinsen, V.: Long-term P weathering and recent $\mathrm{N}$ deposition control contemporary plantsoil C, N, and P, Global Biogeochem. Cy., 30, 231-249, https://doi.org/10.1002/2015GB005167, 2016.

Deinema, M. H., van Loosdrecht, M., and Scholten, A.: Some Physiological Characteristics of Acinetobacter spp. Accumulating Large Amounts of Phosphate, Water Sci. Technol., 17, 119125, https://doi.org/10.2166/wst.1985.0226, 1985.

Delve, R. J., Probert, M. E., Cobo, J. G., Ricaurte, J., Rivera, M., Barrios, E., and Rao, I. M.: Simulating phosphorus responses in annual crops using APSIM: Model evaluation on contrasting soil types, Nutr. Cycl. Agroecosys., 84, 293-306, https://doi.org/10.1007/s10705-008-9243-6, 2009.

Dick, R. P., Rasmussen, P. E., and Kerle, E. A.: Influence of longterm residue management on soil enzyme activities in relation to soil chemical properties of a wheat-fallow system, Biol. Fert. Soils, 6, 159-164, https://doi.org/10.1007/BF00257667, 1988.

Dissing Nielsen, J. and Eiland, F.: Investigations on the relationship between P-fertility, phosphatase activity and ATP content in soil, Plant Soil, 57, 95-103, https://doi.org/10.1007/BF02139645, 1980.

Dodd, R. J. and Sharpley, A. N.: Conservation practice effectiveness and adoption: unintended consequences and implications for sustainable phosphorus management, Nutr. Cycl. Agroecosys., 104, 373-392, https://doi.org/10.1007/s10705-015-9748-8, 2016.

Doolette, A. L., Smernik, R. J., and Dougherty, W. J.: Rapid decomposition of phytate applied to a calcareous soil demonstrated by a solution ${ }^{31} \mathrm{P}$ NMR study, Eur. J. Soil Sci., 61, 563-575, https://doi.org/10.1111/j.1365-2389.2010.01259.x, 2010.
Doolette, A. L., Smernik, R. J., and Dougherty, W. J.: Overestimation of the importance of phytate in $\mathrm{NaOH}$-EDTA soil extracts as assessed by 31P NMR analyses, Org. Geochem., 42, 955-964, https://doi.org/10.1016/j.orggeochem.2011.04.004, 2011.

Dou, Z., Ramberg, C. F., Toth, J. D., Wang, Y., Sharpley, A. N., Boyd, S. E., Chen, C. R., Williams, D., and Xu, Z. H.: Phosphorus Speciation and Sorption-Desorption Characteristics in Heavily Manured Soils, Soil Sci. Soc. Am. J., 73, 93-101, https://doi.org/10.2136/sssaj2007.0416, 2009.

Duncan, E. W., Osmond, D. L., Shober, A. L., Starr, L., Tomlinson, P., Kovar, J. L., Moorman, T. B., Peterson, H. M., Fiorellino, N. M., and Reid, K.: Phosphorus and Soil Health Management Practices, Agric. Environ. Lett., 4, 1-5, https://doi.org/10.2134/ael2019.04.0014, 2019.

Duxbury, J., Smith, M. S., and Doran, J. W.: Soil organic matter as a source and a sink of plant nutrients, in: Dynamics of Soil Organic Matter in Tropical Ecosystems, edited by: Coleman, D., Oades, J. M., and Uehara, G., University of Hawaii Press, Honolulu, Hawaii, 33-67, 1989.

Enwezor, W. O.: Significance of the C: Organic P ratio in the mineralization of soil organic phosphorus, Soil Sci., 103, 62-66, https://doi.org/10.1097/00010694-196701000-00010, 1967.

Enwezor, W. O.: The mineralization of nitrogen and phosphorus in organic materials of varying $\mathrm{C}: \mathrm{N}$ and $\mathrm{C}: \mathrm{P}$ ratios, Plant Soil, 44, 237-240, https://doi.org/10.1007/BF00016972, 1976.

Erich, M. S., Fitzgerald, C. B., and Porter, G. A.: The effect of organic amendments on phosphorus chemistry in a potato cropping system, Agr. Ecosyst. Environ., 88, 79-88, https://doi.org/10.1016/S0167-8809(01)00147-5, 2002.

Findenegg, G. R. and Nelemans, J. A.: The effect of phytase on the availability of $\mathrm{P}$ from myo-inositol hexaphosphate (phytate) for maize roots, Plant Soil, 154, 189-196, https://doi.org/10.1007/BF00012524, 1993.

Fransson, A. M. and Jones, D. L.: Phosphatase activity does not limit the microbial use of low molecular weight organic$\mathrm{P}$ substrates in soil, Soil Biol. Biochem., 39, 1213-1217, https://doi.org/10.1016/j.soilbio.2006.11.014, 2007.

Frossard, E., Condron, L. M., Oberson, A., Sinaj, S., and Fardeau, J. C.: Processes governing phosphorus availability in temperate soils, J. Environ. Qual., 29, 15-23, https://doi.org/10.2134/jeq2000.00472425002900010003x, 2000.

Frossard, E., Achat, D. L., Bernasconi, S. M., Bünemann, E. K., Fardeau, J., Jansa, J., Morel, C., Rabeharisoa, L., Randriamanantsoa, L., Sinaj, S., Tamburini, F., and Oberson, A.: The Use of Tracers to Investigate Phosphate Cycling in Soil-Plant Systems, in: Phosphorus in action: Biological processes in soil phosphorus cycling, Springer, Heidelberg, 59-91, 2011.

Gao, Y., Zhu, B., He, N., Yu, G., Wang, T., Chen, W., and Tian, J.: Phosphorus and carbon competitive sorption-desorption and associated non-point loss respond to natural rainfall events, J. Hydrol., 517, 447-457, https://doi.org/10.1016/j.jhydrol.2014.05.057, 2014.

García, A. M., Alexander, R. B., Arnold, J. G., Norfleet, L., White, M. J., Robertson, D. M., and Schwarz, G.: Regional Effects of Agricultural Conservation Practices on Nutrient Transport in the Upper Mississippi River Basin, Environ. Sci. Technol., 50, 69917000, https://doi.org/10.1021/acs.est.5b03543, 2016. 
George, T. S., Richardson, A. E., Hadobas, P. A., and Simpson, R. J.: Characterization of transgenic Trifolium subterraneum L. which expresses phyA and releases extracellular phytase: Growth and P nutrition in laboratory media and soil, Plant Cell Environ., 27, 1351-1361, https://doi.org/10.1111/j.13653040.2004.01225.x, 2004.

George, T. S., Giles, C. D., Menezes-Blackburn, D., Condron, L. M., Gama-Rodrigues, A. C., Jaisi, D., Lang, F., Neal, A. L., Stutter, M. I., Almeida, D. S., Bol, R., Cabugao, K. G., Celi, L., Cotner, J. B., Feng, G., Goll, D. S., Hallama, M., Krueger, J., Plassard, C., Rosling, A., Darch, T., Fraser, T., Giesler, R., Richardson, A. E., Tamburini, F., Shand, C. A., Lumsdon, D. G., Zhang, H., Blackwell, M. S. A., Wearing, C., Mezeli, M. M., Almås, R., Audette, Y., Bertrand, I., Beyhaut, E., Boitt, G., Bradshaw, N., Brearley, C. A., Bruulsema, T. W., Ciais, P., Cozzolino, V., Duran, P. C., Mora, M. L., de Menezes, A. B., Dodd, R. J., Dunfield, K., Engl, C., Frazão, J. J., Garland, G., González Jiménez, J. L., Graca, J., Granger, S. J., Harrison, A. F., Heuck, C., Hou, E. Q., Johnes, P. J., Kaiser, K., Kjær, H. A., Klumpp, E., Lamb, A. L., Macintosh, K. A., Mackay, E. B., McGrath, J., McIntyre, C., McLaren, T., Mészáros, E., Missong, A., Mooshammer, M., Negrón, C. P., Nelson, L. A., Pfahler, V., Poblete-Grant, P., Randall, M., Seguel, A., Seth, K., Smith, A. C., Smits, M. M., Sobarzo, J. A., Spohn, M., Tawaraya, K., Tibbett, M., Voroney, P., Wallander, H., Wang, L., Wasaki, J., and Haygarth, P. M.: Organic phosphorus in the terrestrial environment: a perspective on the state of the art and future priorities, Plant Soil, 1-18, https://doi.org/10.1007/s11104-017-3391-x, 2017.

Gerke, J.: Phytate (Inositol Hexakisphosphate) in Soil and Phosphate Acquisition from Inositol Phosphates by Higher Plants. A Review, Plants, 4, 253-266, https://doi.org/10.3390/plants4020253, 2015a.

Gerke, J.: The acquisition of phosphate by higher plants: Effect of carboxylate release by the roots. A critical review, J. Plant Nutr. Soil Sc., 178, 351-364, https://doi.org/10.1002/jpln.201400590, $2015 b$.

Gijsman, A. J., Oberson, A., Tiessen, H., and Friesen, D. K.: Limited Applicability of the CENTURY Model to Highly Weathered Tropical Soils, Agron. J., 88, 894-903, https://doi.org/10.2134/agronj1996.00021962003600060008x, 1996.

Giles, C. D. and Cade-Menun, B. J.: Phytate in Animal Manure and Soils: Abundance, Cycling and Bioavailability, in: Applied Manure and Nutrient Chemistry for Sustainable Agriculture and Environment, Springer, Dordrecht, 163-190, 2014.

Giles, C. D., George, T. S., Brown, L. K., Mezeli, M. M., Richardson, A. E., Shand, C. A., Wendler, R., Darch, T., MenezesBlackburn, D., Cooper, P., Stutter, M. I., Lumsdon, D. G., Blackwell, M. S. A., Wearing, C., Zhang, H., and Haygarth, P. M.: Does the combination of citrate and phytase exudation in Nicotiana tabacum promote the acquisition of endogenous soil organic phosphorus?, Plant Soil, 412, 43-59, https://doi.org/10.1007/s11104-016-2884-3, 2017.

Goll, D. S., Brovkin, V., Parida, B. R., Reick, C. H., Kattge, J., Reich, P. B., van Bodegom, P. M., and Niinemets, Ü.: Nutrient limitation reduces land carbon uptake in simulations with a model of combined carbon, nitrogen and phosphorus cycling, Biogeosciences, 9, 3547-3569, https://doi.org/10.5194/bg-9-35472012, 2012.
Goll, D. S., Vuichard, N., Maignan, F., Jornet-Puig, A., Sardans, J., Violette, A., Peng, S., Sun, Y., Kvakic, M., Guimberteau, M., Guenet, B., Zaehle, S., Penuelas, J., Janssens, I., and Ciais, P.: A representation of the phosphorus cycle for ORCHIDEE (revision 4520), Geosci. Model Dev., 10, 3745-3770, https://doi.org/10.5194/gmd-10-3745-2017, 2017.

Grafe, M., Goers, M., von Tucher, S., Baum, C., Zimmer, D., Leinweber, P., Vestergaard, G., Kublik, S., Schloter, M., and Schulz, S.: Bacterial potentials for uptake, solubilization and mineralization of extracellular phosphorus in agricultural soils are highly stable under different fertilization regimes, Environ. Microbiol. Rep., 10, 320-327, https://doi.org/10.1111/17582229.12651, 2018.

Grant, R. F. and Heaney, D. J.: Inorganic phosphorus transformation and transport in soils: Mathematical modeling in ecosys, Soil Sci. Soc. Am. J., 61, 752-764, https://doi.org/10.2136/sssaj1997.03615995006100030008x, 1997.

Greaves, M. P. and Webley, D. M.: The hydrolysis of myoinositol hexaphosphate by soil microorganisms, Soil Biol. Biochem., 1, 37-43, https://doi.org/10.1016/0038-0717(69)90032-7, 1969.

Greenwood, A. J. and Lewis, D. H.: Phosphatases and the utilisation of inositol hexaphosphate by soil yeasts of the genus Cryptococcus, Soil Biol. Biochem., 9, 161-166, https://doi.org/10.1016/0038-0717(77)90069-4, 1977.

Greiner, R.: Phytate-degrading enzymes: Regulation of synthesis in microorganisms and plants, in: Inositol Phosphates: Linking Agriculture and the Environment, edited by: Turner, B. L., Richardson, A. E., and Mulllaney, E. J., CAB International, Wallingford, 78-96, 2007.

Gressel, N., McColl, J. G., Preston, C. M., Newman, R. H., and Powers, R. F.: Linkages between phosphorus transformations and carbon decomposition in a forest soil, Biogeochemistry, 33, 97 123, https://doi.org/10.1007/BF02181034, 1996.

Guo, F., Yost, R. S., Hue, N. V., Evensen, C. I., and Silva, J. A.: Changes in Phosphorus Fractions in Soils under Intensive Plant Growth, Soil Sci. Soc. Am. J., 64, 1681-1689, https://doi.org/10.2136/sssaj2000.6451681x, 2000.

Guppy, C. N. and McLaughlin, M. J.: Options for increasing the biological cycling of phosphorus in low-input and organic agricultural systems, Crop Pasture Sci., 60, 116-123, https://doi.org/10.1071/CP07157, 2009.

Guppy, C. N., Menzies, N. W., Moody, P. W., Compton, B. L., and Blamey, F. P. C.: A simplified, sequential, phosphorus fractionation method, Commun. Soil Sci. Plan., 31, 1981-1991, https://doi.org/10.1080/00103620009370556, 2000.

Guppy, C. N., Menzies, N. W., Moody, P. W., and Blamey, F. P. C.: Competitive sorption reactions between phosphorus and organic matter in soil: A review, Aust. J. Soil Res., 43, 189-202, https://doi.org/10.1071/SR04049, 2005.

Hall, E. K., Maixner, F., Franklin, O., Daims, H., Richter, A., and Battin, T.: Linking Microbial and Ecosystem Ecology Using Ecological Stoichiometry: A Synthesis of Conceptual and Empirical Approaches, Ecosystems, 14, 261-273, https://doi.org/10.1007/s10021-010-9408-4, 2011.

Halstead, R. L.: Phosphatase Activity of Soils as Influenced by Lime and Other Treatments, Can. J. Soil Sci., 44, 137-144, https://doi.org/10.4141/cjss64-017, 1964. 
Harrison, A. F.: Relationship between intensity of phosphatase activity and physico-chemical properties in woodland soils, Soil Biol. Biochem., 15, 93-99, https://doi.org/10.1016/00380717(83)90124-4, 1983.

Harrison, A. F.: Soil organic phosphorus: a review of world literature, Cab International, Wallingord, UK, 1987.

Hartman, W. H. and Richardson, C. J.: Differential Nutrient Limitation of Soil Microbial Biomass and Metabolic Quotients $\left(q \mathrm{CO}_{2}\right)$ : Is There a Biological Stoichiometry of Soil Microbes?, PLoS One, 8, 1-14, https://doi.org/10.1371/journal.pone.0057127, 2013.

Hassink, J. and Whitmore, A. P.: A Model of the Physical Protection of Organic Matter in Soils, Soil Sci. Soc. Am. J., 61, 131-139, https://doi.org/10.2136/sssaj1997.03615995006100010020x, 1997.

Häussling, M. and Marschner, H.: Organic and inorganic soil phosphates and acid phosphatase activity in the rhizosphere of 80year-old Norway spruce [Picea abies (L.) Karst.] trees, Biol. Fert. Soils, 8, 128-133, https://doi.org/10.1007/BF00257756, 1989.

Hayes, J. E., Richardson, A. E., and Simpson, R. J.: Components of organic phosphorus in soil extracts that are hydrolysed by phytase and acid phosphatase, Biol. Fert. Soils, 32, 279-286, https://doi.org/10.1007/s003740000249, 2000.

Heath, R. T.: Microbial turnover of organic phosphorus in aquatic systems, in: Organic Phosphorus in the Environment, edited by: Turner, B. L., Frossard, E., and Baldwin, D. S., CAB International, Wallingford, 185-203, 2005.

Heckrath, G., Brookes, P. C., Poulton, P. R., and Goulding, K. W. T.: Phosphorus Leaching from Soils Containing Different Phosphorus Concentrations in the Broadbalk Experiment, J. Environ. Qual., 24, 904-910, https://doi.org/10.2134/jeq1995.00472425002400050018x, 1995.

Hedley, M. J., Stewart, J. W. B., and Chauhan, B. S.: Changes in Inorganic and Organic Soil Phosphorus Fractions Induced by Cultivation Practices and by Laboratory Incubations, Soil Sci. Soc. Am. J., 46, 970-976, https://doi.org/10.2136/sssaj1982.03615995004600050017x, 1982.

Hedley, M. J., Nye, P. H., and White, R. E.: Plant-Induced Changes in the Rhizosphere of Rape (Brassica Napus Var. Emerald) Seedlings, New Phytol., 95, 69-82, https://doi.org/10.1111/j.1469-8137.1983.tb03470.x, 1983.

Helfenstein, J., Pistocchi, C., Oberson, A., Tamburini, F., Goll, D. S., and Frossard, E.: Estimates of mean residence times of phosphorus in commonly considered inorganic soil phosphorus pools, Biogeosciences, 17, 441-454, https://doi.org/10.5194/bg17-441-2020, 2020.

Heuck, C. and Spohn, M.: Carbon, nitrogen and phosphorus net mineralization in organic horizons of temperate forests: stoichiometry and relations to organic matter quality, Biogeochemistry, 131, 229-242, https://doi.org/10.1007/s10533-016-0276-7, 2016.

Heuck, C., Weig, A., and Spohn, M.: Soil microbial biomass $\mathrm{C}: \mathrm{N}: \mathrm{P}$ stoichiometry and microbial use of organic phosphorus, Soil Biol. Biochem., 85, 119-129, https://doi.org/10.1016/j.soilbio.2015.02.029, 2015.
Hill, J. E. and Richardson, A. E.: Microorganisms That Utilize Phytate, in: Inositol Phosphates: Linking Agriculture and the Environment, edited by: Turner, B. L., Richardson, A. E., and Mulllaney, E. J., CAB International, Wallingford, 61-77, 2007.

Holford, I. C. R., Wedderburn, R. W. M., and Mattingly, G. E. G.: A Langmuir Two-Surface Eqaution as a Model for Phosphate Adsorption by Soils, J. Soil Sci., 25, 242-255, https://doi.org/10.1111/j.1365-2389.1974.tb01121.x, 1974.

Holtan, H., Kamp-Nielsen, L., and Stuanes, A. O.: Phosphorus in soil, water and sediment: an overview, Hydrobiologia, 170, 1934, https://doi.org/10.1007/BF00024896, 1988.

Hooda, P. S., Rendell, A. R., Edwards, A. C., Withers, P. J. A., Aitken, M. N., and Truesdale, V. W.: Relating Soil Phosphorus Indices to Potential Phosphorus Release to Water, J. Environ. Qual., 29, 1166-1171, https://doi.org/10.2134/jeq2000.00472425002900040018x, 2000.

Houlton, B. Z., Wang, Y. P., Vitousek, P. M., and Field, C. B.: A unifying framework for dinitrogen fixation in the terrestrial biosphere, Nature, 454, 327-330, https://doi.org/10.1038/nature07028, 2008.

Hubel, F. and Beck, E.: Maize Root Phytase (Purification, Characterization, and Localization of Enzyme Activity and Its Putative Substrate), Plant Physiol., 112, 1429-1436, https://doi.org/10.1104/pp.112.4.1429, 1996.

Hunt, J. F., Ohno, T., He, Z., Honeycutt, C. W., and Dail, D. B.: Inhibition of phosphorus sorption to goethite, gibbsite, and kaolin by fresh and decomposed organic matter, Biol. Fert. Soils, 44, 277-288, https://doi.org/10.1007/s00374-007-0202-1, 2007.

Hussain, A., Murtaza, G., Ghafoor, A., and Mehdi, S. M.: Use of Two-Surface Langmuir-Type Equations for Assessment of Phosphorus Requirements of Lentil on Differently Textured Alluvial Soils, Commun. Soil Sci. Plan., 43, 2575-2589, https://doi.org/10.1080/00103624.2012.716121, 2012.

Idriss, E. E., Makarewicz, O., Farouk, A., Rosner, K., Greiner, R., Bochow, H., Richter, T., and Borriss, R.: Extracellular phytase activity of Bacillus amyloliquefaciens FZB45 contributes to its plant-growth-promoting effect, Microbiology, 148, 2097-2109, https://doi.org/10.1099/00221287-148-7-2097, 2002.

Jackman, R. H. and Black, C. A.: Solubility of Iron, Aluminum, Calcium, and Magnesium Inositol Phosphates at Different pH Values, Soil Sci., 72, 179-186, https://doi.org/10.1097/00010694-195109000-00002, 1951.

Jones, C. A., Cole, C. V., Sharpley, A. N., and Williams, J. R.: A Simplified Soil and Plant Phosphours Model: I. Documentation, Soil Sci. Soc. Am. J., 48, 800-805, 1984.

Jones, D. L., Nguyen, C., and Finlay, R. D.: Carbon flow in the rhizosphere: Carbon trading at the soil-root interface, Plant Soil, 321, 5-33, https://doi.org/10.1007/s11104-009-9925-0, 2009.

Jørgensen, C., Turner, B. L., and Reitzel, K.: Identification of inositol hexakisphosphate binding sites in soils by selective extraction and solution ${ }^{31} \mathrm{P}$ NMR spectroscopy, Geoderma, 257, 2228, https://doi.org/10.1016/j.geoderma.2015.03.021, 2015.

Joshi, S. R., Li, X., and Jaisi, D. P.: Transformation of Phosphorus Pools in an Agricultural Soil: An Application of Oxygen18 Labeling in Phosphate, Soil Sci. Soc. Am. J., 80, 69-78, https://doi.org/10.2136/sssaj2015.06.0219, 2016.

Joshi, S., Li, W., Bowden, M., and Jaisi, D.: Sources and Pathways of Formation of Recalcitrant and Residual 
Phosphorus in an Agricultural Soil, Soil Syst., 2, 45, https://doi.org/10.3390/soilsystems2030045, 2018.

Juma, N. G. and Tabatabai, M. A.: Effects of Trace Elements on Phosphatase Activity in Soils, Soil Sci. Soc. Am. J., 41, 343-346, https://doi.org/10.2136/sssaj1977.03615995004100020034x, 1977.

Juma, N. G. and Tabatabai, M. A.: Distribution of phosphomonoesterases in soils, Soil Sci., 126, 101-108, https://doi.org/10.1097/00010694-197808000-00006, 1978.

Kemanian, A. R. and Stöckle, C. O.: C-Farm: A simple model to evaluate the carbon balance of soil profiles, Eur. J. Agron., 32, 22-29, https://doi.org/10.1016/j.eja.2009.08.003, 2010.

Kemanian, A. R., Julich, S., Manoranjan, V. S., and Arnold, J. R.: Integrating soil carbon cycling with that of nitrogen and phosphorus in the watershed model SWAT: Theory and model testing, Ecol. Model., 222, 1913-1921, https://doi.org/10.1016/j.ecolmodel.2011.03.017, 2011.

Kirkby, C. A., Kirkegaard, J. A., Richardson, A. E., Wade, L. J., Blanchard, C., and Batten, G.: Stable soil organic matter: A comparison of $C: N: P: S$ ratios in Australian and other world soils, Geoderma, 163, 197-208, https://doi.org/10.1016/j.geoderma.2011.04.010, 2011.

Kleinman, P. J. A. and Sharpley, A. N.: Estimating soil phosphorus sorption saturation from Mehlich-3 data, Commun. Soil Sci. Plan., 33, 1825-1839, https://doi.org/10.1081/CSS-120004825, 2002.

Knisel, W. G.: CREAMS: A field-scale model for chemicals, runoff, and erosion from agricultural management systems, USDA National Resources Conservation Service, Washington, DC, 1980.

Kruse, J., Abraham, M., Amelung, W., Baum, C., Bol, R., Kühn, O., Lewandowski, H., Niederberger, J., Oelmann, Y., Rüger, C., Santner, J., Siebers, M., Siebers, N., Spohn, M., Vestergren, J., Vogts, A., and Leinweber, P.: Innovative methods in soil phosphorus research: A review, J. Plant Nutr. Soil Sc., 178, 43-88, https://doi.org/10.1002/jpln.201400327, 2015.

Kulaev, I., Vagabov, V., and Kulakovskaya, T.: New aspects of inorganic polyphosphate metabolism and function, $J$. Biosci. Bioeng., 88, 111-129, https://doi.org/10.1016/S13891723(99)80189-3, 1999.

Lang, F., Krüger, J., Amelung, W., Willbold, S., Frossard, E., Bünemann, E. K., Bauhus, J., Nitschke, R., Kandeler, E., Marhan, S., Schulz, S., Bergkemper, F., Schloter, M., Luster, J., Guggisberg, F., Kaiser, K., Mikutta, R., Guggenberger, G., Polle, A., Pena, R., Prietzel, J., Rodionov, A., Talkner, U., Meesenburg, H., von Wilpert, K., Hölscher, A., Dietrich, H. P., and Chmara, I.: Soil phosphorus supply controls $\mathrm{P}$ nutrition strategies of beech forest ecosystems in Central Europe, Biogeochemistry, 136, 5-29, https://doi.org/10.1007/s10533-017-0375-0, 2017.

Leonard, R. A., Knisel, W. G., and Still, D. A.: GLEAMS: Groundwater Loading Effects of Agricultural Management Systems, T. ASAE, 30, 1403-1418, https://doi.org/10.13031/2013.30578, 1987.

Leytem, A. B., Smith, D. R., Applegate, T. J., and Thacker, P. A.: The Influence of Manure Phytic Acid on Phosphorus Solubility in Calcareous Soils, Soil Sci. Soc. Am. J., 70, 1629-1638, https://doi.org/10.2136/sssaj2006.0003, 2006.

Li, L., Liang, X., Ye, Y., Zhao, Y., Zhang, Y., Jin, Y., Yuan, J., and Chen, Y.: Effects of repeated swine manure applications on legacy phosphorus and phosphomonoesterase ac- tivities in a paddy soil, Biol. Fert. Soils, 51, 167-181, https://doi.org/10.1007/s00374-014-0956-1, 2015.

Li, M., Osaki, M., Rao, I. M., and Tadano, T.: Secretion of phytase from the roots of several plant species under phosphorus-deficient conditions, Plant Soil, 195, 161-169, https://doi.org/10.1023/A:1004264002524, 1997.

Liang, Y. and Blake, R. E.: Oxygen isotope composition of phosphate in organic compounds: Isotope effects of extraction methods, Org. Geochem., 37, 1263-1277, https://doi.org/10.1016/j.orggeochem.2006.03.009, 2006.

Lilienfein, J., Qualls, R. G., Uselman, S. M., and Bridgham, S. D.: Adsorption of Dissolved Organic and Inorganic Phosphorus in Soils of a Weathering Chronosequence, Soil Sci. Soc. Am. J., 68, 620-628, https://doi.org/10.2136/sssaj2004.6200, 2004.

Lima, J. A., Nahas, E., and Gomes, A. C.: Microbial populations and activities in sewage sludge and phosphate fertilizer-amended soil, Appl. Soil Ecol., 4, 75-82, https://doi.org/10.1016/09291393(96)00094-7, 1996.

Limousin, G., Gaudet, J. P., Charlet, L., Szenknect, S., Barthès, V., and Krimissa, M.: Sorption isotherms: A review on physical bases, modeling and measurement, Appl. Geochem., 22, 249275, https://doi.org/10.1016/j.apgeochem.2006.09.010, 2007.

Lung, S. C. and Lim, B. L.: Assimilation of phytate-phosphorus by the extracellular phytase activity of tobacco (Nicotiana tabacum) is affected by the availability of soluble phytate, Plant Soil, 279, 187-199, https://doi.org/10.1007/s11104-005-1009-1, 2006.

Lung, S. C., Chan, W. L., Yip, W., Wang, L., Yeung, E. C., and Lim, B. L.: Secretion of beta-propeller phytase from tobacco and Arabidopsis roots enhances phosphorus utilization, Plant Sci., 169, 341-349, https://doi.org/10.1016/j.plantsci.2005.03.006, 2005.

Maguire, R. O. and Sims, J. T.: Measuring Agronomic and Environmental Soil Phosphorus Saturation and Predicting Phosphorus Leaching with Mehlich 3, Soil Sci. Soc. Am. J., 66, 2033 2039, https://doi.org/10.2136/sssaj2002.2033, 2002.

Manzoni, S., Jackson, R. B., Trofymow, J. A., and Porporato, A.: The Global Stoichiometry of Litter Nitrogen Mineralization, Science, 321, 684-686, https://doi.org/10.1126/science.1159792, 2008.

Manzoni, S., Trofymow, J. A., Jackson, R. B., and Porporato, A.: Stoichiometric controls on carbon, nitrogen, and phosphorus dynamics in decomposing litter, Ecol. Monogr., 80, 89-106, https://doi.org/10.1890/09-0179.1, 2010.

Margalef, O., Sardans, J., Fernández-Martínez, M., MolownyHoras, R., Janssens, I. A., Ciais, P., Goll, D., Richter, A., Obersteiner, M., Asensio, D., and Peñuelas, J.: Global patterns of phosphatase activity in natural soils, Sci. Rep., 7, 1-13, https://doi.org/10.1038/s41598-017-01418-8, 2017.

Marklein, A. R. and Houlton, B. Z.: Nitrogen inputs accelerate phosphorus cycling rates across a wide variety of terrestrial ecosystems, New Phytol., 193, 696-704, https://doi.org/10.1111/j.1469-8137.2011.03967.x, 2012.

Marklein, A. R., Winbourne, J. B., Enders, S. K., Gonzalez, D. J. X., van Huysen, T. L., Izquierdo, J. E., Light, D. R., Liptzin, D., Miller, K. E., Morford, S. L., Norton, R. A., and Houlton, B. Z.: Mineralization ratios of nitrogen and phosphorus from decomposing litter in temperate versus tropical forests, Global. Ecol. Biogeogr., 25, 335-346, https://doi.org/10.1111/geb.12414, 2016. 
Mazzilli, S. R., Kemanian, A. R., Ernst, O. R., Jackson, R. B., and Piñeiro, G.: Priming of soil organic carbon decomposition induced by corn compared to soybean crops, Soil Biol. Biochem., 75, 273-281, https://doi.org/10.1016/j.soilbio.2014.04.005, 2014.

McDowell, R. W., Cade-Menun, B., and Stewart, I.: Organic phosphorus speciation and pedogenesis: Analysis by solution ${ }^{31} \mathrm{P}$ nuclear magnetic resonance spectroscopy, Eur. J. Soil Sci., 58, 1348-1357, https://doi.org/10.1111/j.1365-2389.2007.00933.x, 2007.

McGechan, M. B. and Lewis, D. R.: Sorption of phosphorus by soil, part 1: Principles, equations and models, Biosyst. Eng., 82, 1-24, https://doi.org/10.1006/bioe.2002.0054, 2002.

McGill, W. B. and Cole, C. V.: Comparative aspects of cycling of organic C, N, S and P through soil organic matter, Geoderma, 26, 267-286, https://doi.org/10.1016/0016-7061(81)90024-0, 1981.

McKercher, R. B. and Anderson, G.: Organic phosphate sorption by neutral and basic soils, Commun. Soil Sci. Plan., 20, 723-732, https://doi.org/10.1080/00103628909368112, 1989.

McLaughlin, M. J., McBeath, T. M., Smernik, R., Stacey, S. P., Ajiboye, B., and Guppy, C.: The chemical nature of P accumulation in agricultural soils-implications for fertiliser management and design: An Australian perspective, Plant Soil, 349, 69-87, https://doi.org/10.1007/s11104-011-0907-7, 2011.

Menezes-Blackburn, D., Zhang, H., Stutter, M., Giles, C. D., Darch, T., George, T. S., Shand, C., Lumsdon, D., Blackwell, M., Wearing, C., Cooper, P., Wendler, R., Brown, L., and Haygarth, P. M.: A Holistic Approach to Understanding the Desorption of Phosphorus in Soils, Environ. Sci. Technol., 50, 3371-3381, https://doi.org/10.1021/acs.est.5b05395, 2016.

Moller, A., Kaiser, K., Amelung, W., Niamskul, C., Udomsri, S., Puthawong, M., Haumaier, L., and Zech, W.: Forms of organic $\mathrm{C}$ and $\mathrm{P}$ extracted from tropical soils as assessed by liquid-state ${ }^{13}$ C- and ${ }^{31}$ P-NMR spectroscopy, Aust. J. Soil Res., 38, $1017-$ 1035, https://doi.org/10.1071/SR99111, 2000.

Mooshammer, M., Wanek, W., Zechmeister-Boltenstern, S., and Richter, A.: Stoichiometric imbalances between terrestrial decomposer communities and their resources: Mechanisms and implications of microbial adaptations to their resources, Front. Microbiol., 5, 1-10, https://doi.org/10.3389/fmicb.2014.00022, 2014.

Moscatelli, M. C., Lagomarsino, A., De Angelis, P., and Grego, S.: Seasonality of soil biological properties in a poplar plantation growing under elevated atmospheric $\mathrm{CO}_{2}$, Appl. Soil Ecol., 30, 162-173, https://doi.org/10.1016/j.apsoil.2005.02.008, 2005.

Mullaney, E. J. and Ullah, A. H. J.: Phytases: Attributes, catalytic mechanisms and applications, in: Inositol Phosphates: Linking Agriculture and the Environment, edited by: Turner, B. L., Richardson, A. E., and Mulllaney, E. J., CAB International, Wallingford, 97-110, 2007.

Nannipieri, P., Johnson, R. L., and Paul, E. A.: Criteria for measurement of microbial growth and activity in soil, Soil Biol. Biochem., 10, 223-229, https://doi.org/10.1016/00380717(78)90100-1, 1978.

Nannipieri, P., Giagnoni, L., Landi, L., and Renella, G.: Role of Phosphatase Enzymes in Soil, in: Phosphorus in action: Biological processes in soil phosphorus cycling, Springer, Heidelberg, 215-243, 2011.
Oburger, E., Jones, D. L., and Wenzel, W. W.: Phosphorus saturation and $\mathrm{pH}$ differentially regulate the efficiency of organic acid anion-mediated $\mathrm{P}$ solubilization mechanisms in soil, Plant Soil, 341, 363-382, https://doi.org/10.1007/s11104-010-0650-5, 2011.

Oehl, F., Frossard, E., Fliessbach, A., Dubois, D., and Oberson, A.: Basal organic phosphorus mineralization in soils under different farming systems, Soil Biol. Biochem., 36, 667-675, https://doi.org/10.1016/j.soilbio.2003.12.010, 2004.

Ognalaga, M., Frossard, E., and Thomas, F.: Glucose-1phosphate and Myo-inositol Hexaphosphate Adsorption Mechanisms on Goethite, Soil Sci. Soc. Am. J., 58, 332-337, https://doi.org/10.2136/sssaj1994.03615995005800020011x, 1994.

Ohno, T. and Crannell, B. S.: Green and Animal ManureDerived Dissolved Organic Matter Effects on Phosphorus Sorption, J. Environ. Qual., 25, 1137-1143, https://doi.org/10.2134/jeq1996.00472425002500050029x, 1996.

Okajima, H., Kubota, H., and Sakuma, T.: Hysteresis in the phosphorus sorption and desorption processes of soils, Soil Sci. Plant Nutr., 29, 271-283, https://doi.org/10.1080/00380768.1983.10434628, 1983.

Olander, L. P. and Vitousek, P. M.: Regulation of soil phosphatase and chitinase activity by $\mathrm{N}$ and $\mathrm{P}$ availability, Biogeochemistry, 49, 175-190, https://doi.org/10.1023/A:1006316117817, 2000.

Ozanne, P. G.: Phosphate Nutrition of Plants - a General Treatise, in: The Role of Phosphorus in Agriculture, ASA, CSSA, and SSSA, Madison, WI, 559-589, 1980.

Patel, K. J., Singh, A. K., Nareshkumar, G., and Archana, G.: Organic-acid-producing, phytate-mineralizing rhizobacteria and their effect on growth of pigeon pea (Cajanus cajan), Appl. Soil Ecol., 44, 252-261, https://doi.org/10.1016/j.apsoil.2010.01.002, 2010.

Pierzynski, G. M.: The chemistry and mineralogy of phosphorus in excessively fertilized soils, Crit. Rev. Env. Contr., 21, 265-295, https://doi.org/10.1080/10643389109388418, 1991.

Pistocchi, C., Mészáros, É., Tamburini, F., Frossard, E., and Bünemann, E. K.: Biological processes dominate phosphorus dynamics under low phosphorus availability in organic horizons of temperate forest soils, Soil Biol. Biochem., 126, 64-75, https://doi.org/10.1016/j.soilbio.2018.08.013, 2018.

Pravia, M. V., Kemanian, A. R., Terra, J. A., Shi, Y., Macedo, I., and Goslee, S.: Soil carbon saturation, productivity, and carbon and nitrogen cycling in crop-pasture rotations, Agr. Syst., 171, 13-22, https://doi.org/10.1016/j.agsy.2018.11.001, 2019.

Quiquampoix, H. and Mousain, D.: Enzymatic Hydrolysis of Organic Phosphorus, in Organic Phosphorus in the environment, edited by: Turner, B. L., Frossard, E., and Baldwin, D. S., CAB International, Wallingford, 89-112, 2005.

Radcliffe, D. E., Freer, J., and Schoumans, O.: Diffuse phosphorus models in the United States and europe: their usages, scales, and uncertainties, J. Environ. Qual., 38, 1956-1967, https://doi.org/10.2134/jeq2008.0060, 2009.

Radcliffe, D. E., Reid, D. K., Blombäck, K., Bolster, C. H., Collick, A. S., Easton, Z. M., Francesconi, W., Fuka, D. R., Johnsson, H., King, K., Larsbo, M., Youssef, M. A., Mulkey, A. S., Nelson, N. O., Persson, K., Ramirez-Avila, J. J., Schmieder, F., and Smith, D. R.: Applicability of Models to Predict Phospho- 
rus Losses in Drained Fields: A Review, J. Environ. Qual., 44, 614-628, https://doi.org/10.2134/jeq2014.05.0220, 2015.

Reddy, K. R., Overcash, M. R., Khaleel, R., and Westerman, P. W.: Phosphorus adsorption-desorption characteristics of two soils utilized for disposal of animal wastes, J. Environ. Qual., 9, 8692, https://doi.org/10.2134/jeq1980.00472425000900010020x, 1980.

Reed, S. C., Yang, X., and Thornton, P. E.: Incorporating phosphorus cycling into global modeling efforts: A worthwhile, tractable endeavor, New Phytol., 208, 324-329, https://doi.org/10.1111/nph.13521, 2015.

Regelink, I. C., Weng, L., Lair, G. J., and Comans, R. N. J.: Adsorption of phosphate and organic matter on metal (hydr)oxides in arable and forest soil: A mechanistic modelling study, Eur. J. Soil Sci., 66, 867-875, https://doi.org/10.1111/ejss.12285, 2015.

Richardson, A. E. and Simpson, R. J.: Soil Microorganisms Mediating Phosphorus Availability, Plant Physiol., 156, 989-996, https://doi.org/10.1104/pp.111.175448, 2011.

Richardson, A. E., Hadobas, P. A., and Hayes, J. E.: Acid phosphomonoesterase and phytase activities of wheat (Triticum aestivum L.) roots and utilization of organic phosphorus substrates by seedlings grown in sterile culture, Plant Cell Environ., 23, 397-405, https://doi.org/10.1046/j.1365-3040.2000.00557.x, 2000.

Richardson, A. E., Hadobas, P. A., and Hayes, J. E.: Extracellular secretion of Aspergillus phytase from Arabidopsis roots enables plants to obtain phosphorus from phytate, Plant J., 25, 641-649, https://doi.org/10.1046/j.1365-313X.2001.00998.x, 2001.

Richardson, A. E., Barea, J. M., McNeill, A. M., and PrigentCombaret, C.: Acquisition of phosphorus and nitrogen in the rhizosphere and plant growth promotion by microorganisms, Plant Soil, 321, 305-339, https://doi.org/10.1007/s11104-009-9895-2, 2009a.

Richardson, A. E., Hocking, P. J., Simpson, R. J., and George, T. S.: Plant Mechanisms to Optimise Access to Soil Phosphorus, Crop Pasture Sci., 60, 124-143, https://doi.org/10.1071/CP07125, $2009 b$.

Richter, D. D., Allen, H. L., Li, J., Markewitz, D., and Raikes, J.: Bioavailability of slowly cycling soil phosphorus: Major restructuring of soil $\mathrm{P}$ fractions over four decades in an aggrading forest, Oecologia, 150, 259-271, https://doi.org/10.1007/s00442-0060510-4, 2006.

Roberts, K., Defforey, D., Turner, B. L., Condron, L. M., Peek, S., Silva, S., Kendall, C., and Paytan, A.: Oxygen isotopes of phosphate and soil phosphorus cycling across a 6500 year chronosequence under lowland temperate rainforest, Geoderma, 257-258, 14-21, https://doi.org/10.1016/j.geoderma.2015.04.010, 2015.

Rojo, M. J., Carcedo, S. G., and Mateos, M. P.: Distribution and characterization of phosphatase and organic phosphorus in soil fractions, Soil Biol. Biochem., 22, 169-174, https://doi.org/10.1016/0038-0717(90)90082-B, 1990.

Schimel, J. P. and Weintraub, M. N.: The implications of exoenzyme activity on microbial carbon and nitrogen limitation in soil: A theoretical model, Soil Biol. Biochem., 35, 549-563, doi:10.1016/S0038-0717(03)00015-4, 2003.

Sharpley, A. N., Jones, C. A., Gray, C., and Cole, C. V.: A Simplified Soil and Plant Phosphorus Model: II. Prediction of Labile, Organic, and Sorbed Phosphorus, Soil Sci. Soc. Am. J., 48, 805-809, https://doi.org/10.2136/sssaj1984.03615995004800040021x, 1984.

Shang, C., Huang, P. M., and Stewart, J. W. B.: Kinetics of Adsorption of Organic and Inorganic Phosphates ny Short-Range Ordered Precipitate of Aluminum, Can. J. Soil Sci., 70, 461-470, https://doi.org/10.4141/cjss90-045, 1990.

Shang, C., Stewart, J. W. B., and Huang, P. M.: pH effect on kinetics of adsorption of organic and inorganic phosphates by shortrange ordered aluminum and iron precipitates, Geoderma, 53, 114, https://doi.org/10.1016/0016-7061(92)90017-2, 1992.

Siebers, N., Bauke, S. L., Tamburini, F., and Amelung, W.: Shortterm impacts of forest clear-cut on $\mathrm{P}$ accessibility in soil microaggregates: An oxygen isotope study, Geoderma, 315, 59-64, https://doi.org/10.1016/j.geoderma.2017.11.024, 2018.

Sinsabaugh, R. L., Antibus, R. K., Linkins, A. E., McClaugherty, C. A., Rayburn, L., Repert, D., and Weiland, T.: Wood Decomposition: Nitrogen and Phosphorus Dynamics in Relation to Extracellular Enzyme Activity, Ecology, 74, 1586-1593, https://doi.org/10.2307/1940086, 1993.

Sinsabaugh, R. L., Hill, B. H., and Follstad Shah, J. J.: Ecoenzymatic stoichiometry of microbial organic nutrient acquisition in soil and sediment, Nature, 462, 795-798, https://doi.org/10.1038/nature08632, 2009.

Six, J., Conant, R. T., Paul, E. A., and Paustian, K.: Stabilization mechanisms of soil organic matter: Implications for C-saturatin of soils, Plant Soil, 241, 155-176, https://doi.org/10.1023/A:1016125726789, 2002.

Steffens, D., Leppin, T., Luschin-Ebengreuth, N., Min Yang, Z., and Schubert, S.: Organic soil phosphorus considerably contributes to plant nutrition but is neglected by routine soil-testing methods, J. Plant Nutr. Soil Sci., 173, 765-771, https://doi.org/10.1002/jpln.201000079, 2010.

Smeck, N. E.: Phosphorus dynamics in soils and landscapes, Geoderma, 36, 185-199, https://doi.org/10.1016/00167061(85)90001-1, 1985.

Smernik, R. J. and Dougherty, W. J.: Identification of Phytate in Phosphorus-31 Nuclear Magnetic Resonance Spectra: The Need for Spiking, Soil Sci. Soc. Am. J., 71, 1045-1050, https://doi.org/10.2136/sssaj2006.0295, 2007.

Speir, T. W. and Cowling, J. C.: Phosphatase activities of pasture plants and soils: Relationship with plant productivity and soil P fertility indices, Biol. Fert. Soils, 12, 189-194, https://doi.org/10.1007/BF00337200, 1991.

Spiers, G. A. and McGill, W. B.: Effects of phosphorus addition and energy supply on acid phosphatase production and activity in soils, Soil Biol. Biochem., 11, 3-8, https://doi.org/10.1016/00380717(79)90110-X, 1979.

Spohn, M. and Kuzyakov, Y:: Phosphorus mineralization can be driven by microbial need for carbon, Soil Biol. Biochem., 61, 69-75, https://doi.org/10.1016/j.soilbio.2013.02.013, 2013.

Spohn, M., Ermak, A., and Kuzyakov, Y.: Microbial gross organic phosphorus mineralization can be stimulated by root exudates A ${ }^{33} \mathrm{P}$ isotopic dilution study, Soil Biol. Biochem., 65, 254-263, https://doi.org/10.1016/j.soilbio.2013.05.028, 2013.

Spohn, M., Treichel, N. S., Cormann, M., Schloter, M., and Fischer, D.: Distribution of phosphatase activity and various bacterial phyla in the rhizosphere of Hordeum vulgare L. depending on $\mathrm{P}$ availability, Soil Biol. Biochem., 89, 44-51, https://doi.org/10.1016/j.soilbio.2015.06.018, 2015. 
Staunton, S. and Leprince, F.: Effect of $\mathrm{pH}$ and some organic anions on the solubility of soil phosphate: Implications for P bioavailability, Eur. J. Soil Sci., 47, 231-239, https://doi.org/10.1111/j.1365-2389.1996.tb01394.x, 1996.

Steenbergh, A. K., Bodelier, P. L. E., Hoogveld, H. L., Slomp, C. P., and Laanbroek, H. J.: Phosphatases relieve carbon limitation of microbial activity in Baltic Sea sediments along a redox-gradient, Limnol. Oceanogr., 56, 2018-2026, https://doi.org/10.4319/lo.2011.56.6.2018, 2011.

Stewart, J. W. B. and Tiessen, H.: Dynamics of soil organic phosphorus, Biogeochemistry, 4, 41-60, https://doi.org/10.1007/BF02187361, 1987.

Sun, M. and Jaisi, D. P.: Distribution of inositol phosphates in animal feed grains and excreta: distinctions among isomers and phosphate oxygen isotope compositions, Plant Soil, 430, 291305, https://doi.org/10.1007/s11104-018-3723-5, 2018.

Tang, J. Y. and Riley, W. J.: A total quasi-steady-state formulation of substrate uptake kinetics in complex networks and an example application to microbial litter decomposition, Biogeosciences, 10, 8329-8351, https://doi.org/10.5194/bg-10-8329-2013, 2013.

Tamburini, F., Bernasconi, S. M., Angert, A., Weiner, T., and Frossard, E.: A method for the analysis of the $\delta^{18} \mathrm{O}$ of inorganic phosphate extracted from soils with $\mathrm{HCl}$, Eur. J. Soil Sci., 61, 1025-1032, https://doi.org/10.1111/j.1365-2389.2010.01290.x, 2010.

Tamburini, F., Pfahler, V., von Sperber, C., Frossard, E., and Bernasconi, S. M.: Oxygen Isotopes for Unraveling Phosphorus Transformations in the Soil-Plant System: A Review, Soil Sci. Soc. Am. J., 78, 38-46, https://doi.org/10.2136/sssaj2013.05.0186dgs, 2014.

Tamburini, F., Pistocchi, C., Helfenstein, J., and Frossard, E.: A method to analyse the isotopic composition of oxygen associated with organic phosphorus in soil and plant material, Eur. J. Soil Sci., 69, 816-826, https://doi.org/10.1111/ejss.12693, 2018.

Tang, J., Leung, A., Leung, C., and Lim, B. L.: Hydrolysis of precipitated phytate by three distinct families of phytases, Soil Biol. Biochem., 38, 1316-1324, https://doi.org/10.1016/j.soilbio.2005.08.021, 2006.

Tarafdar, J. C. and Claassen, N.: Organic phosphorus utilization by wheat plants under sterile conditions, Biol. Fert. Soils, 39, 25-29, https://doi.org/10.1007/s00374-003-0671-9, 2003.

Tarafdar, J. C. and Jungk, A.: Phosphatase activity in the rhizosphere and its relation to the depletion of soil organic phosphorus, Biol. Fert. Soils, 3, 199-204, https://doi.org/10.1007/BF00640630, 1987.

Taranto, M. T., Adams, M. A., and Polglase, P. J.: Sequential fractionation and characterisation ( $\left.{ }^{31} \mathrm{P}-\mathrm{NMR}\right)$ of phosphorus-amended soils in Banksia integrifolia (L.f.) woodland and adjacent pasture, Soil Biol. Biochem., 32, 169-177, https://doi.org/10.1016/S0038-0717(99)00138-8, 2000.

Thompson, L. M., Black, C. A., and Zoellner, J. A.: Occurrence and mineralization of organic phosphorus in soils, with particular reference to associations with nitrogen, carbon, and pH, Soil Sci., 77, 185-196, https://doi.org/10.1097/00010694195403000-00002, 1954.

Thum, T., Caldararu, S., Engel, J., Kern, M., Pallandt, M., Schnur, R., Yu, L., and Zaehle, S.: A new model of the coupled carbon, nitrogen, and phosphorus cycles in the terrestrial biosphere
(QUINCY v1.0; revision 1996), Geosci. Model Dev., 12, 47814802, https://doi.org/10.5194/gmd-12-4781-2019, 2019.

Tiessen, H. and Moir, J. O.: Characterization of available P by sequential extraction, in: Soil Sampling and Methods of Analysis, edited by: Carter, M. R. and Gregorich, E. G., Taylor \& Francis, Boca Raton, FL, 75-86, 1993.

Tipping, E., Somerville, C. J., and Luster, J.: The $C: N: P: S$ stoichiometry of soil organic matter, Biogeochemistry, 130, 117131, https://doi.org/10.1007/s10533-016-0247-z, 2016.

Trasar-Cepeda, M. C., Carballas, T., Gil-Sotres, F., and de Blas, E.: Liming and the phosphatase activity and mineralization of phosphorus in an andic soil, Soil Biol. Biochem., 23, 209-215, https://doi.org/10.1016/0038-0717(91)90054-N, 1991.

Turner, B. L.: Inositol phosphates in soil: Amounts, forms and significance of the phosphorylated inositol stereoisomers, in: Inositol Phosphates: Linking Agriculture and the Environment, 186206, CAB International, Wallingford., 2007.

Turner, B. L.: Resource partitioning for soil phosphorus: A hypothesis, J. Ecol., 96, 698-702, https://doi.org/10.1111/j.13652745.2008.01384.x, 2008.

Turner, B. L. and Blackwell, M. S. A.: Isolating the influence of $\mathrm{pH}$ on the amounts and forms of soil organic phosphorus, Eur. J. Soil Sci., 64, 249-259, https://doi.org/10.1111/ejss.12026, 2013.

Turner, B. L. and Joseph Wright, S.: The response of microbial biomass and hydrolytic enzymes to a decade of nitrogen, phosphorus, and potassium addition in a lowland tropical rain forest, Biogeochemistry, 117, 115-130, https://doi.org/10.1007/s10533013-9848-y, 2014.

Turner, B. L., Papházy, M. J., Haygarth, P. M., and Mckelvie, I. D.: Inositol phosphates in the environment, Philos. T. Roy. Soc. B, 357, 449-469, https://doi.org/10.1098/rstb.2001.0837, 2002.

Turner, B. L., Condron, L. M., Richardson, S. J., Peltzer, D. A., and Allison, V. J.: Soil Organic Phosphorus Transformations During Pedogenesis, Ecosystems, 10, 1166-1181, https://doi.org/10.1007/s10021-007-9086-z, 2007.

Vadas, P. A. and White, M. J.: Validating Soil Phosphorus Routines in the SWAT Model, Trans. ASABE, 53, 1469-1476, https://doi.org/10.13031/2013.34897, 2010.

Vadas, P. A., Krogstad, T., and Sharpley, A. N.: Modeling Phosphorus Transfer between Labile and Nonlabile Soil Pools, Soil Sci. Soc. Am. J., 70, 736-743, https://doi.org/10.2136/sssaj2005.0067, 2006.

Vadas, P. A., Bolster, C. H., and Good, L. W.: Critical evaluation of models used to study agricultural phosphorus and water quality, Soil Use Manag., 29, 36-44, https://doi.org/10.1111/j.14752743.2012.00431.x, 2013.

van der Zee, S. E. A. T. M. and van Riemsdijk, W. H.: Model for Long-term Phosphate Reaction Kinetics in Soil, J. Environ. Qual., 17, 35-41, https://doi.org/10.2134/jeq1988.00472425001700010005x, 1988.

Vincent, A. G., Turner, B. L., and Tanner, E. V. J.: Soil organic phosphorus dynamics following perturbation of litter cycling in a tropical moist forest, Eur. J. Soil Sci., 61, 48-57, https://doi.org/10.1111/j.1365-2389.2009.01200.x, 2010.

Walbridge, M. R., Richardson, C. J., and Swank, W. T.: Vertical Distribution of Biological and Geochemical Phosphorus Subcycles in two Southern Appalachian Forest Soils, Biogeochemistry, 13, 61-85, 1991. 
Wang, J., Wu, Y., Zhou, J., Bing, H., and Sun, H.: Carbon demand drives microbial mineralization of organic phosphorus during the early stage of soil development, Biol. Fert. Soils, 52, 825-839, https://doi.org/10.1007/s00374-016-1123-7, 2016.

Wang, S., Jin, X., Zhao, H., Zhou, X., and Wu, F.: Effect of organic matter on the sorption of dissolved organic and inorganic phosphorus in lake sediments, Colloid. Surface. A, 297, 154162, https://doi.org/10.1016/j.colsurfa.2006.10.040, 2007.

Wang, Y. P., Law, R. M., and Pak, B.: A global model of carbon, nitrogen and phosphorus cycles for the terrestrial biosphere, Biogeosciences, 7, 2261-2282, https://doi.org/10.5194/bg-7-22612010, 2010.

Wanner, B. L.: Phosphorus Assimilation and Control of the Phosphate Regulon, in: Escherichia coli and Salmonella typhimurium: Cellular and Molecular Biology, Vol. 1, American Society for Microbiology, Washington, DC, 1357-1381, 1996.

Waring, B. G., Averill, C., and Hawkes, C. V.: Differences in fungal and bacterial physiology alter soil carbon and nitrogen cycling: Insights from meta-analysis and theoretical models, Ecol. Lett., 16, 887-894, https://doi.org/10.1111/ele.12125, 2013.

White, C. M., Kemanian, A. R., and Kaye, J. P.: Implications of carbon saturation model structures for simulated nitrogen mineralization dynamics, Biogeosciences, 11, 6725-6738, https://doi.org/10.5194/bg-11-6725-2014, 2014.

Wieder, W. R., Grandy, A. S., Kallenbach, C. M., and Bonan, G. B.: Integrating microbial physiology and physio-chemical principles in soils with the MIcrobial-MIneral Carbon Stabilization (MIMICS) model, Biogeosciences, 11, 3899-3917, https://doi.org/10.5194/bg-11-3899-2014, 2014.

Williams, C. and Steinbergs, A.: Sulphur and phosphorus in some Eastern Australian soils, Aust. J. Agr. Res., 9, 483-491, https://doi.org/10.1071/AR9580483, 1958.

Wutzler, T., Zaehle, S., Schrumpf, M., Ahrens, B., and Reichstein, M.: Adaptation of microbial resource allocation affects modelled long term soil organic matter and nutrient cycling, Soil Biol. Biochem., 115, 322-336, https://doi.org/10.1016/j.soilbio.2017.08.031, 2017.

$\mathrm{Xu}, \mathrm{X}$., Thornton, P. E., and Post, W. M.: A global analysis of soil microbial biomass carbon, nitrogen and phosphorus in terrestrial ecosystems, Global. Ecol. Biogeogr., 22, 737-749, https://doi.org/10.1111/geb.12029, 2013.
Yan, Y., Li, W., Yang, J., Zheng, A., Liu, F., Feng, X., and Sparks, D. L.: Mechanism of myo-inositol hexakisphosphate sorption on amorphous aluminum hydroxide: Spectroscopic evidence for rapid surface precipitation, Environ. Sci. Technol., 48, 67356742, https://doi.org/10.1021/es500996p, 2014.

Yang, X. and Post, W. M.: Phosphorus transformations as a function of pedogenesis: A synthesis of soil phosphorus data using Hedley fractionation method, Biogeosciences, 8, 2907-2916, https://doi.org/10.5194/bg-8-2907-2011, 2011.

Yu, L., Zanchi, G., Akselsson, C., Wallander, H., and Belyazid, S.: Modeling the forest phosphorus nutrition in a southwestern Swedish forest site, Ecol. Model., 369, 88-100, https://doi.org/10.1016/j.ecolmodel.2017.12.018, 2018.

Yu, L., Ahrens, B., Wutzler, T., Schrumpf, M., and Zaehle, S.: Jena Soil Model (JSM v1.0; revision 1934): a microbial soil organic carbon model integrated with nitrogen and phosphorus processes, Geosci. Model Dev., 13, 783-803, https://doi.org/10.5194/gmd-13-783-2020, 2020.

Zechmeister-Boltenstern, S., Keiblinger, K. M., Mooshammer, M., Peñuelas, J., Richter, A., Sardans, J., and Wanek, W.: The application of ecological stoichiometry to plant-microbial-soil organic matter transformations, Ecol. Monogr., 85, 133-155, https://doi.org/10.1890/14-0777.1, 2015.

Zhang, H., Schroder, J. L., Fuhrman, J. K., Basta, N. T., Storm, D. E., and Payton, M. E.: Path and Multiple Regression Analyses of Phosphorus Sorption Capacity, Soil Sci. Soc. Am. J., 69, 96, https://doi.org/10.2136/sssaj2005.0096dup, 2005.

Zhou, Y., Boutton, T. W., and Wu, X. B.: Soil phosphorus does not keep pace with soil carbon and nitrogen accumulation following woody encroachment, Global Change Biol., 24, 1992-2007, https://doi.org/10.1111/gcb.14048, 2018.

Zhu, Q., Riley, W. J., Tang, J., Collier, N., Hoffman, F. M., Yang, X., and Bisht, G.: Representing Nitrogen, Phosphorus, and Carbon Interactions in the E3SM Land Model: Development and Global Benchmarking, J. Adv. Model. Earth Sy., 11, 2238-2258, https://doi.org/10.1029/2018MS001571, 2019.

Zohar, I., Shaviv, A., Klass, T., Roberts, K., and Paytan, A.: Method for the Analysis of Oxygen Isotopic Composition of Soil Phosphate Fractions, Environ. Sci. Technol., 44, 7583-7588, https://doi.org/10.1021/es100707f, 2010. 